\title{
The Elicitor Protein AsES Induces a Systemic Acquired Resistance Response Accompanied by Systemic Microbursts and Micro-Hypersensitive Responses in Fragaria ananassa
}

\author{
Verónica Hael-Conrad, ${ }^{1}$ Silvia Marisa Perato, ${ }^{1}$ Marta Eugenia Arias, ${ }^{2}$ Martín Gustavo Martínez-Zamora, ${ }^{1}$ \\ Pía de los Ángeles Di Peto, ${ }^{3}$ Gustavo Gabriel Martos, ${ }^{1}$ Atilio Pedro Castagnaro, ${ }^{3}$ \\ Juan Carlos Díaz-Ricci, ${ }^{1}$ and Nadia Regina Chalfoun ${ }^{3,+}$ \\ ${ }^{1}$ Instituto Superior de Investigaciones Biológicas (INSIBIO), CONICET-UNT, and Instituto de Química Biológica "Dr. Bernabé \\ Bloj", Facultad de Bioquímica, Química y Farmacia, UNT. Chacabuco 461, T4000ILI, San Miguel de Tucumán, Argentina; \\ ${ }^{2}$ Cátedra de Anatomía Vegetal, Facultad de Ciencias Naturales e Instituto Miguel Lillo, Universidad Nacional de Tucumán. \\ Miguel Lillo 205, 4000, Tucumán, Argentina, and Facultad de Ciencias Exactas y Naturales, Universidad Nacional de \\ Catamarca. Av. Belgrano 300, 4700, San Fernando del Valle de Catamarca, Catamarca, Argentina; and ${ }^{3}$ Instituto de Tecnología \\ Agroindustrial del Noroeste Argentino (ITANOA, CONICET-Estación Experimental Agroindustrial Obispo Colombres). Av. \\ William Cross 3150, T4101XAC, Las Talitas, Tucumán, Argentina
}

Accepted 19 June 2017.

The elicitor AsES (Acremonium strictum elicitor subtilisin) is a 34-kDa subtilisin-like protein secreted by the opportunistic fungus Acremonium strictum. AsES activates innate immunity and confers resistance against anthracnose and gray mold diseases in strawberry plants (Fragaria $\times$ ananassa Duch.) and the last disease also in Arabidopsis. In the present work, we show that, upon AsES recognition, a cascade of defense responses is activated, including: calcium influx, biphasic oxidative burst $\left(\mathrm{O}_{2}^{--}\right.$and $\left.\mathrm{H}_{2} \mathrm{O}_{2}\right)$, hypersensitive cell-death response (HR), accumulation of autofluorescent compounds, cell-wall reinforcement with callose and lignin deposition, salicylic acid accumulation, and expression of defense-related genes, such as FaPR1, FaPG1, FaMYB30, FaRBOH-D, FaRBOH-F, FaCHI23, and $\mathrm{FaFLS}$. All these responses occurred following a spatial and temporal program, first induced in infiltrated leaflets (local acquired resistance), spreading out to untreated lateral leaflets, and later, to distal leaves (systemic acquired resistance). After AsES treatment, macro-HR and macro-oxidative bursts were localized in infiltrated leaflets, while micro-HRs and microbursts occurred later in untreated leaves, being confined to a single cell or a cluster of a few epidermal cells that differentiated from the surrounding ones. The differentiated cells initiated a timedependent series of physiological and anatomical changes,

Sequence data is available in the GenBank/EMBL databases under the following accession numbers: FaPRI (AB462752), FaPG1 (DQ458990), FaRBOH-D $\quad($ KX583680.1), $\quad$ FaRBOH-F $\quad$ (KX583677.1), $\quad$ FaCHI23 (AB201755), FaFLS (DQ087252), FaPRX27 (AFQ36036), and from an expressed sequence tag with high similarity with FaSAGT (CO817016.1). The FaEF-1 $\alpha$, FaMYB30, FaGSL5, and FaSAMES nucleotide sequence data reported are available in the Third Party Annotation Section of the GenBank/EMBL/DDBJ databases under accession numbers: BK009992 to BK009995, respectively.

${ }^{\dagger}$ Corresponding author: N. R. Chalfoun; E-mail: nadiarchal@yahoo.com.ar

*The $\boldsymbol{e}$-Xtra logo stands for "electronic extra" and indicates that four supplementary figures are published online.

๑) 2018 The American Phytopathological Society evolving to idioblasts accumulating $\mathrm{H}_{2} \mathrm{O}_{2}$ and autofluorescent compounds that blast, delivering its content into surrounding cells. This kind of systemic cell-death process in plants is described for the first time in response to a single elicitor. All data presented in this study suggest that AsES has the potential to activate a wide spectrum of biochemical and molecular defense responses in $F$. ananassa that may explain the induced protection toward pathogens of opposite lifestyle, like hemibiotrophic and necrotrophic fungi.

Plants have evolved a sophisticated and efficient immune system to repel pathogen attacks. Some pathogens can circumvent constitutive barriers such as cuticle, cell wall, and antimicrobial phytoanticipins (Newman et al. 2013; Underwood 2012), but plants induce a two-branched innate immune response (Jones and Dangl 2006). First, transmembrane pattern recognition receptors sense "non-self" signals associated to microbes such as pathogen associated molecular patterns (PAMPs), and microbe associated molecular patterns or "self" break-down products known as damage-associated molecular patterns (DAMPs) (Boller and Felix 2009; Ferrari et al. 2013; Garcion et al. 2007; Zipfel et al. 2004) activating a relatively weak immune response called PAMP-triggered immunity (PTI). Dynamic coevolution of plants lead to the production of resistance $(\mathrm{R})$ proteins that specifically recognize virulence effectors derived from specialized pathogens, resulting in effector-triggered immunity (ETI), that consists of an amplified response that usually culminates in a hypersensitive cell-death response (HR) at the infection site (Deslandes and Rivas 2012; Jones and Dangl 2006). Both PTI and ETI occur at the initial site of infection, triggering a local acquired resistance (LAR), characterized by ion influxes to the cytosol, generation of reactive oxygen species (ROS) (Doke 1983) and nitric oxide (Lamotte et al. 2005), and activation of mitogen-activated protein kinase (MAPK) signaling pathways (Pedley and Martin 2005). These reactions induce a transcriptional reprogramming of defense gene expression leading to the accumulation of defense-related compounds such as phytoalexins (Grayer and Kokubun 2001; Harborne 1999), 
pathogenesis-related proteins (PR) (Van Loon and van Strien 1999), and phytohormones (Robert-Seilaniantz et al. 2007, 2011), while cell walls are strengthened by callose and lignin depositions (Humphreys and Chapple 2002; Lewis 1999; Nicholson and Hammerschmidt 1992; Thordal-Christensen et al. 1997). PTI and ETI are regulated by the phytohormones salicylic acid (SA), jasmonic acid (JA), and ethylene (ET), which are the main hormones responsible for activating the whole plant, triggering a systemic acquired resistance (SAR).

Many biological elicitors, such as proteins, peptides, glycoproteins, lipids, oligosaccharides, and oligogalacturonides, have been described to induce protection in different plant-pathogen interaction systems (Henry et al. 2012; Wiesel et al. 2014). Since their application is becoming an interesting agricultural practice as an alternative to hazardous agrochemical control (De Wit et al. 2009; Walters et al. 2013; Wiesel et al. 2014), the characterization of their mode of action in a well-known plant-pathogen interaction system became necessary.

AsES (Acremonium strictum elicitor subtilisin) is an extracellular subtilisin-like protein of 288 aa and $34 \mathrm{kDa}$ (GenBank accession number JX684014) (Chalfoun et al. 2013), secreted by the opportunistic fungal pathogen Acremonium strictum (Racedo et al. 2013). Interestingly, this protein exhibits a significant similarity to precursors of extracellular serine proteases that belong to the subfamily of proteinase K-like subtilisins (S8A) produced by several fungal species but low similarity (less than 45\%) with the completely sequenced proteases from Acremonium sp. (Chalfoun et al. 2013). The AsES elicitor confers full protection against anthracnose, under controlled conditions in strawberry plants (Fragaria $\times$ ananassa Duch.), caused by the hemibiotrophic fungus Colletotrichum acutatum (Chalfoun et al. 2013). AsESinduced protection toward anthracnose is characterized by a monophasic ROS burst and upregulation of a chitinase and PRI gene expression. In addition, it was shown that AsES confers protection against Botrytis cinerea in Arabidopsis thaliana through the activation of the three main defense signaling pathways mediated by SA, JA, and ET, as demonstrated using the transgenic plant nahG and the mutants nprl, ics1, coil.16, jarl, dde2.1, ein2, and etrl (Hael-Conrad et al. 2015). Such promising results boosted the development of a sustainable strategy using AsES protein as a phytosanitary management practice in strawberry and other crops (Castagnaro et al. 2012). However, AsES-triggered defense signaling network in strawberry remains mostly unknown. With the aim to characterize the defensive response induced by this elicitor in strawberry, numerous PTI- and ETI-associated defense mechanisms were assessed. In the present work, we demonstrated that, upon AsES recognition, a cascade of events are activated, first locally in treated tissues and then systemically in untreated ones, following a spatial and temporal pattern organized in different cellular layers of foliar tissue. Among the observed defense reactions activated by AsES are calcium influx, a biphasic oxidative burst, HR response, accumulation of phenolic compounds (PCs), cell-wall reinforcement by callose and lignin depositions, SA accumulation, and the upregulation of some defense-related genes, namely, FaPRl, FaPG1, FaMYB30, FaRBOH-D, FaRBOH-F, $\mathrm{FaCHI} 3$, and FaFLS.

\section{RESULTS}

\section{AsES induces a biphasic macro-oxidative burst and calcium influx in foliar treated tissue.}

In previous work, Chalfoun et al. (2013) reported that AsES induces a punctual oxidative burst $4 \mathrm{~h}$ posttreatment (hpt) in strawberry plants. With the aim to further characterize AsESinduced ROS accumulation (superoxide $\left[\mathrm{O}_{2}^{\circ-}\right]$ and hydrogen peroxide $\left[\mathrm{H}_{2} \mathrm{O}_{2}\right]$ ) in strawberry, plants were mock- or AsES-sprayed to run-off and were analyzed over a broad lapse of time after treatment. A typical biphasic oxidative burst was detected for both $\mathrm{O}_{2}^{*-}$ and $\mathrm{H}_{2} \mathrm{O}_{2}$ in AsES-treated plants (Fig. $1 \mathrm{~A}$ and $\mathrm{B}$ ) as compared with mock-treated ones in which no ROS accumulation could be detected (Supplementary Fig. S1). For $\mathrm{O}_{2}^{--}$, a first minor peak occurred between 1 and $1.5 \mathrm{hpt}$, while a second peak was stronger, persisted longer in time, and peaked between 4 and 5 hpt (Fig. 1A). In the case of $\mathrm{H}_{2} \mathrm{O}_{2}$, it also accumulated immediately between 1 and $1.5 \mathrm{hpt}$, then decreased to background levels and peaked again between 4 and $5 \mathrm{hpt}$, decreasing until $12 \mathrm{hpt}$ (Fig. 1B). Interestingly, for $\mathrm{H}_{2} \mathrm{O}_{2}$, in contrast to $\mathrm{O}_{2}^{\cdot-}$, both bursts reached similar intensity.

In order to validate whether AsES infiltration also induced an oxidative burst, ROS were analyzed in mock- and AsES-infiltrated leaflets (IL). Analyses of $\mathrm{O}_{2}^{--}$and $\mathrm{H}_{2} \mathrm{O}_{2}$ showed that the former strongly accumulated $5 \mathrm{hpt}$ (Supplementary Fig. S2), whereas the latter mainly $4 \mathrm{hpt}$, coinciding with the second peak observed previously (Fig. 1).

Moreover, AsES-treated leaves accumulated $\mathrm{Ca}^{2+}$ in parenchyma cells and trichoma by $1 \mathrm{hpt}$, which was observed as green areas under UV light, in comparison with basal levels observed in mock-treated leaves (Fig. 2, indicated by arrows).
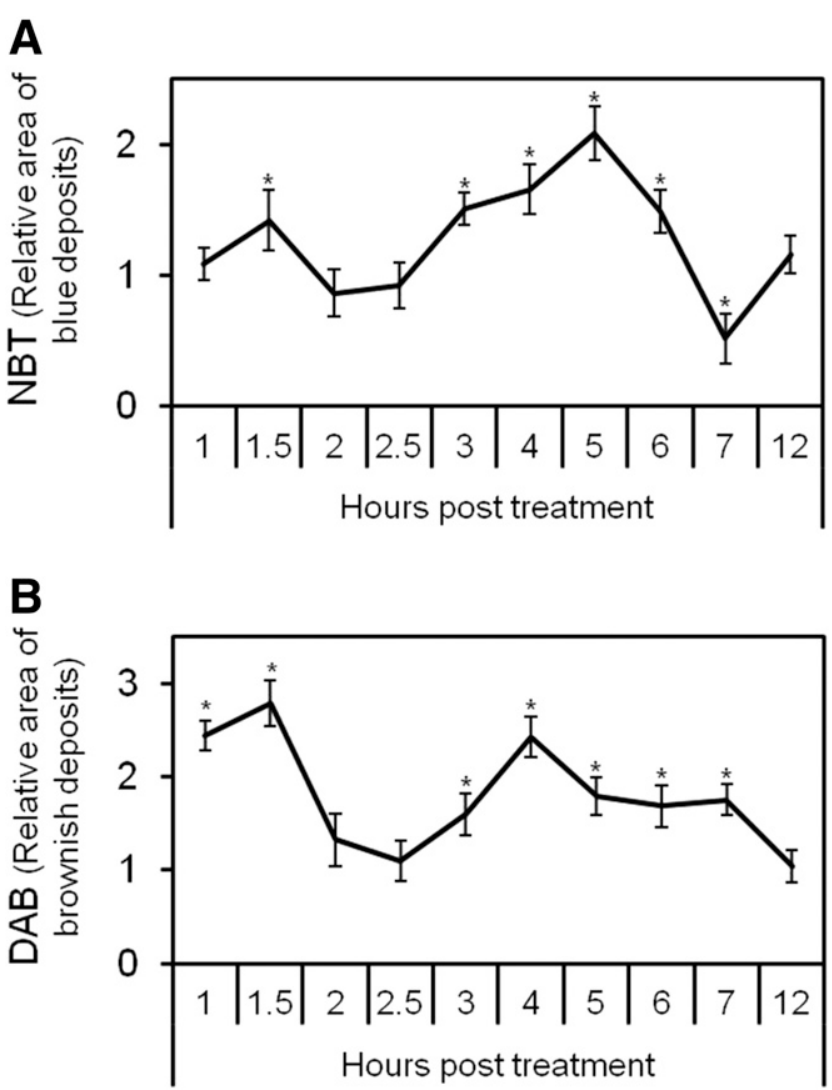

Fig. 1. A biphasic oxidative burst is induced in AsES-sprayed strawberry plants. A, Accumulation of superoxide anion $\left(\mathrm{O}_{2}^{--}\right)$and $\mathbf{B}$, hydrogen peroxide $\left(\mathrm{H}_{2} \mathrm{O}_{2}\right)$ was analyzed in local tissue from mock- and AsES-sprayed plants $1,1.5,2,2.5,3,4,5,6$, and $12 \mathrm{~h}$ posttreatment (hpt) by nitroblue tetrazolium (NBT) and 3,3'-diaminobenzidine (DAB) staining methods, respectively. Quantification of reactive oxygen species accumulation was performed by measurement of the area with blue $\left(\mathrm{O}_{2}^{-}\right)$and brownish $\left(\mathrm{H}_{2} \mathrm{O}_{2}\right)$ deposits in mock- and AsES-treated leaves with ImageJ software and is expressed as relative area. Mean values \pm standard error are represented from one typical assay $(n=5)$. Asterisks indicate a statistically significant difference between AsES-treated plants and the correspondent mock, according to Student's $t$ test $(P<0.05)$. Two independent assays were performed with similar results. 
AsES activates the accumulation of autofluorescent compounds and necrosis in infiltrated foliar tissue.

In general, a calcium influx and oxidative burst precede and activate programmed cell death during plant defense responses; therefore, we explored whether AsES could induce a local HR in strawberry leaves. At $4 \mathrm{hpt}$, leaves showed no HR, but at 12 hpt, an incipient necrosis localized in the area of AsES-IL was observed as compared with the mock (Fig. 3A). Thereafter, necrosis progressed through $24 \mathrm{hpt}$ and covered the entire area of the AsES-IL $72 \mathrm{hpt}$. Nevertheless, the immediately surrounding tissue remained symptomless (Fig. 3A). Necrosis was spatially and temporally accompanied by the appearance of autofluorescence in AsES-IL when observed under UV light (Fig. 3B). Initially, a bright, yellow-colored autofluorescence was observed, but as necrosis progressed, the color changed to green (Fig. 3B). Therefore, autofluorescence occurrence correlated with necrosis progress in AsES-IL, in contraposition to normal tissues observed in the mock-IL. To further study this phenomenon, accumulation of PCs was quantified in mockand AsES-IL. AsES-induced soluble and cell wall-bound PC accumulation was detected at $72 \mathrm{hpt}$, suggesting a correlation between PC accumulation and occurrence of autofluorescence (Supplementary Fig. S3).

\section{AsES induces systemic micro-oxidative bursts and micro-HRs.}

In line with previous results in which it was shown that AsES induces a systemic protection against $C$. acutatum in strawberry (Chalfoun et al. 2013) and B. cinerea in Arabidopsis (Hael-Conrad et al. 2015), we decided to study whether microscopic defenserelated events initiated at mock- or AsES-IL were systemically propagated to untreated leaflets of the same leaf (proximal leaflets [PL]), distal untreated leaves (DL), or both. Microscopic observations of AsES-PL revealed that micro-oxidative bursts took place from 2 to $6 \mathrm{hpt}$ (Fig. 4), following a behavior similar to that exhibited in AsES-IL, as shown in Figure 1. While $\mathrm{H}_{2} \mathrm{O}_{2}$ was predominantly accumulated adjacent to veins (Fig. 4A, indicated by arrows), $\mathrm{O}_{2}^{--}$was observed as discrete punctual areas around

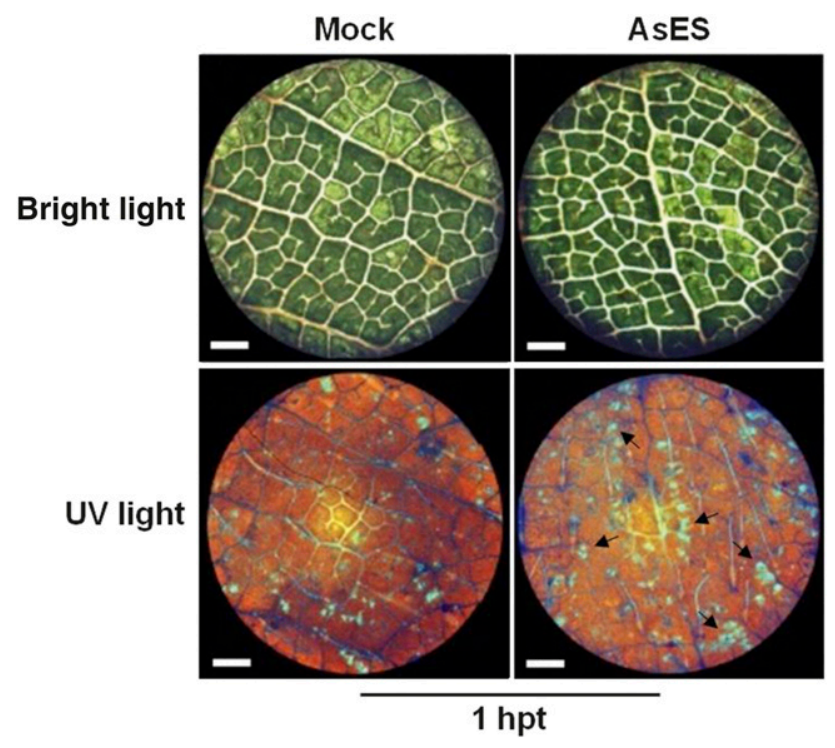

Fig. 2. AsES induces a calcium influx in strawberry leaf disks. Calcium accumulation was analyzed in mock- and AsES-treated leaf disks $1 \mathrm{~h}$ posttreatment (hpt), using the fluorescent probe Fura2-AM, and was visualized under bright and UV light. Green areas (marked with arrows) indicate the presence of calcium. Ten independent assays were performed $(n=10)$. One representative image is used to illustrate results of each treatment. Bars $=300 \mu \mathrm{m}$. them (Fig. 4B, indicated by arrows). Both ROS declined $6 \mathrm{hpt}$ and became imperceptible at $12 \mathrm{hpt}$.

In contrast to AsES-induced HR in IL, no macroscopic and systemic necrosis was visualized in PL and DL (data not shown). However, when analyzing histological transverse sections under light microscopy, morphological and anatomical changes were detected 4 hpt in PL from AsES-treated leaves (Fig. 5). Microscopic analysis of this tissue showed that some cells of the cuticle and adaxial epidermis swelled (Fig. 5B, indicated by arrows) when compared with mock-treated tissue (Fig. 5A). These cells were assumed to be idioblasts, since they exhibited a clearly different phenotype (larger volume), probably associated with the accumulation of content related to defense compounds. In fact, some of these idioblasts were found to continue to swell until bursting, releasing their cellular content to the extracellular matrix, which was observed as a diffuse layer on the cuticle in Figure 5C (thick arrow); a collapsed and shrunk idioblast is also observed (Fig. 5C, thin arrow). When histological preparations were illuminated under UV light, autofluorescence was observed in isolated cells and in reduced aggregates of epidermal cells of AsES-PL as well (Fig. 5E). As described previously, some of these cells burst and the cellular content was liberated, which was visualized as diffuse green autofluorescence (Fig. 5F) under UV light. All these data together suggest that some epidermal cells of AsES-PL undergo cell death in a two-step HR-like process, by increasing their volume first, as a consequence of the accumulation of autofluorescent compounds, and then, hatching and liberating it. Neither idioblast nor green fluorescence was observed in PL of mock-treated leaves (Fig. 5D).

When DL of AsES-infiltrated plants were analyzed, ROS microbursts were observed $24 \mathrm{hpt}$ (Fig. 6). Similarly to what was observed in PL, $\mathrm{H}_{2} \mathrm{O}_{2}$ was mainly formed in veins and surrounding zones (Fig. 6B, indicated by arrows), while $\mathrm{O}_{2}^{\cdot-}$ was distributed in a well-defined regular punctual pattern along the surface of DL (Fig. 6E, indicated by arrows). When studying both types of microbursts under higher resolution, it was observed that $\mathrm{H}_{2} \mathrm{O}_{2}$ accumulated in the apoplast of abaxial epidermis cells (Fig. 6C), while $\mathrm{O}_{2}^{--}$was produced in chloroplasts of mesophyll cells (Fig. 6F). To determine whether distal foliar tissue exhibiting oxidative microbursts in response to AsES treatment also produced micro-HRs, microscopic observations under UV light were carried out. As shown in Figure 6H, microHRs were clearly visualized as punctual brilliant spots sticking out from the background. When analyzed under a higher resolution, autofluorescence was observed in small cell clusters of the abaxial epidermis, and notoriously, a collapsed cell was visualized as a black hole (Fig. 6I, indicated by arrow). Based on these observations, it is possible to establish that microbursts and micro-HRs present a similar distribution pattern among the leaf tissue of AsES-treated strawberry plants.

\section{AsES induces SA accumulation.}

When SA was assessed as a systemic defense parameter in phloem sap extracted from the petioles of mock- and AsES-treated leaves, a transient accumulation profile associated with SAR was detected (Fig. 7). AsES induced the accumulation of SA as early as $24 \mathrm{hpt}$ and peaked at $48 \mathrm{hpt}$, reaching a concentration of $3.15 \mu \mathrm{g}$ per microgram of leaf fresh weight $(\mathrm{FW})$, which was twofold higher than the amount detected in mock-treated plants $(1.53 \mu \mathrm{g}$ per microgram of leaf $\mathrm{FW}$ ), and then, SA content decreased to basal levels after $120 \mathrm{hpt}(1.36 \mu \mathrm{g}$ per microgram of leaf $\mathrm{FW})$.

AsES induces systemic lignin and callose accumulation.

Since AsES was shown to induce early defense signaling responses at the whole-plant level, it was expected that other downstream events associated to defense response were also induced in strawberry plants. Therefore, lignin and callose deposition 
were assessed in both PL and DL of mock- and AsES-treated plants. Depositions of both polymers were first observed at $12 \mathrm{hpt}$ in PL of plants treated with the elicitor (Fig. 8B and D). In comparison, no deposition of lignin or callose was detected in mocktreated plants (Fig. 8A and C). However, cell-wall reinforcement and thickening was observed 7 days posttreatment (dpt) in DL of AsES-infiltrated tissue (Fig. 8F and I), as compared with mockinfiltrated (Fig. 8E and H). Noteworthy, cell walls of stomatal guard cells were reinforced with lignin (Fig. 8G) and callose (Fig. 8J, box insert), as were the cells forming the base of a trichoma (Fig. 8K).

\section{AsES induces expression of defense-related genes.}

In order to further analyze AsES-triggered immunity, gene expression of selected genes was evaluated by quantitative polymerase chain reaction (qPCR) in mock- and AsES-treated leaves at different time points after treatment. The study included FaPRI (pathogenesis-related protein1), a SA-responsive SAR marker gene, FaPGl (polygalacturonase1), encoding for a cell wall-degrading enzyme, FaRBOH-D and FaRBOH-F (respiratory burst oxidase homologs D and F), two main NADPH oxidases of membrane involved in apoplastic ROS burst, FaMYB30, a HR marker gene, and biosynthetic enzymes related to different branches of the phenylpropanoid pathway, such as $\mathrm{FaCHI} 23$ (chalcone isomerase 23), which specifically participates in synthesis of flavones and isoflavones, FaFLS (flavonol synthase), related to flavonol synthesis, FaGSL5 (glucan synthase-like 5), a gene involved in callose synthesis, and, finally, FaPRX27 (class III plant peroxidase), involved in lignin biosynthesis. Additionally, the expression of two genes related to SA metabolism was studied, i.e., SA glycosyltransferase (FaSAGT) and a SA methylesterase (FaSAMES).

Regarding FaPRl, the expression was up-regulated in AsEStreated plants in a two-peak profile with a twofold induction between 72 and $96 \mathrm{hpt}$ and a more significant ninefold induction reached at $144 \mathrm{hpt}$ (Fig. 9A). The FaPGl gene was induced 23-fold at $144 \mathrm{hpt}$ (Fig. 9B), suggesting its participation in AsES-triggered defense response. FaRBOH-D showed a very similar pattern of induction as $F a P G 1$, with low or no expression changes at early time points after AsES treatment, but it was induced 20-fold at $144 \mathrm{hpt}$ (Fig. 9C). The other ROSassociated gene $F a R B O H-F$ showed a very different pattern of induction, as a fivefold induction after $48 \mathrm{hpt}$ was followed by a second eightfold increase in expression at $168 \mathrm{hpt}$ (Fig. 9D). The HR marker gene FaMYB30 showed much less pronounced
A

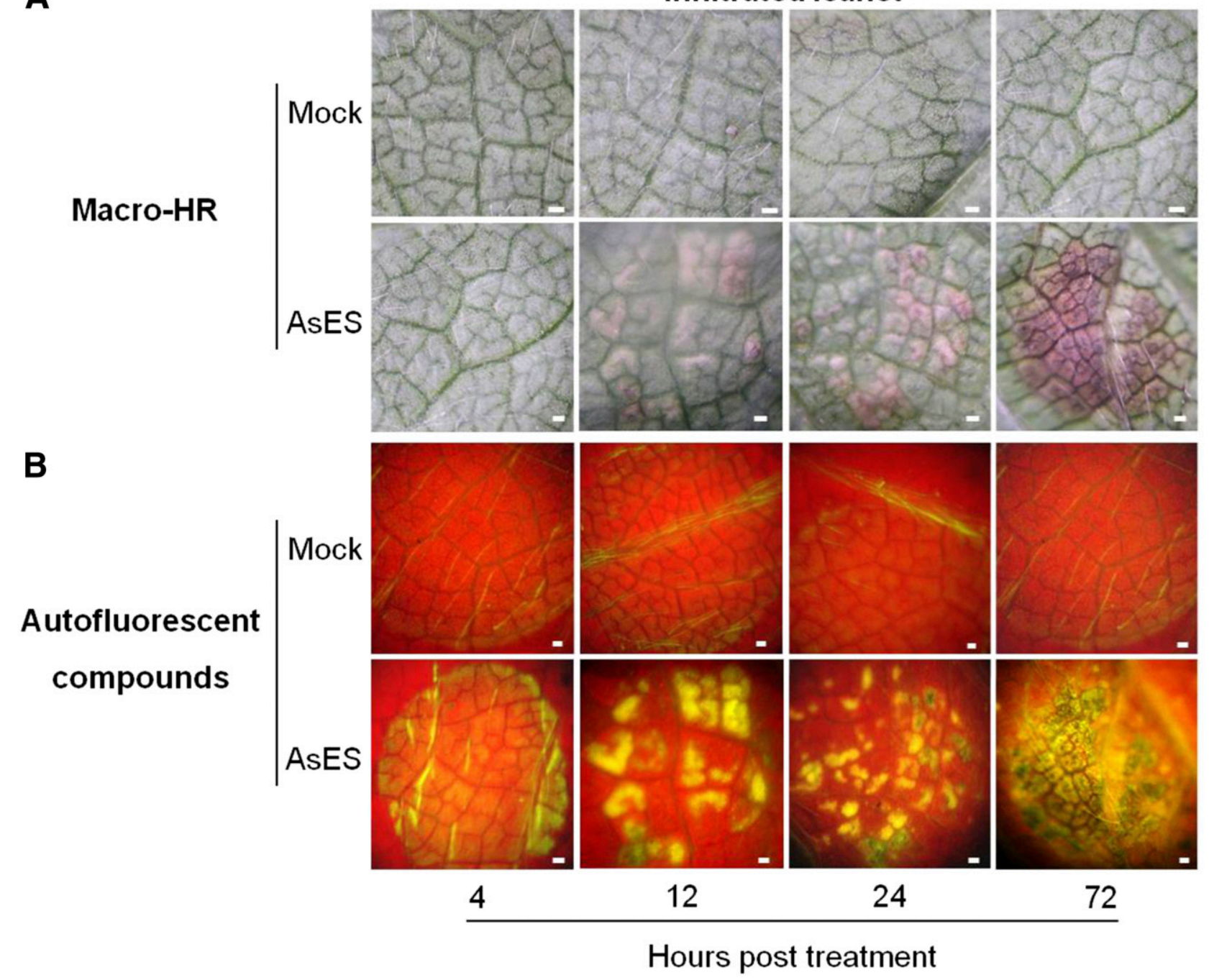

Fig. 3. AsES induces spatial and temporal macro hypersensitive cell-death response (Macro-HR) and autofluorescence production in infiltrated leaflets. A, Detection of cell death and $\mathbf{B}$, determination of autofluorescent compounds was analyzed in vivo in mock- and AsES-infiltrated leaflets $4,12,24$, and $72 \mathrm{~h}$ posttreatment. Necrosis was visualized under bright field and autofluorescence under UV light in microscope. Three independent assays were performed $(n=5)$ with similar observations. One representative image is used to illustrate results of each treatment. Bars $=100 \mu \mathrm{m}$. 
differences in expression levels and it was induced twofold at 48 hpt, and later, from 144 to $168 \mathrm{hpt}$, a threefold second induction was detected (Fig. 9E). An almost identical expression pattern as described for FaMYB3O was observed for FaCHI23, in which expression was up-regulated threefold at 48 and $144 \mathrm{hpt}$, with respect to mock-treated plants (Fig. 9F). The second gene of the phenylpropanoid pathway analyzed, $F a F L S$, demonstrated a very similar expression pattern to FaPGI and FaRBOH-D genes, with no induction at early time points and a strong (23-fold) increase in gene expression at 144 hpt (Fig. 9G). Regarding FaGSL5, associated with callose synthesis, AsES induced its expression around threefold at 144 and $168 \mathrm{hpt}$ (Fig. 9H). Also, AsES treatment induced a low two-peak expression pattern for FaPRX27 between 48 and 72 hpt, first, and then at $144 \mathrm{hpt}$ (around 1.5- and twofold), similar to the gene expression described for genes FaMYB3O and FaCHI23 (Fig. 9I). Finally, no significant expression change was detected for any of SA-related genes (FaSAGT and FaSAMES) in AsES-treated plants with respect to the mock (Supplementary Fig. S4).

\section{DISCUSSION}

Interconnection among ROS, HR, and PC accumulation during AsES-induced LAR.

In the present work, we have demonstrated that AsES triggers both LAR and SAR in a time-dependent manner in strawberry plants. First, AsES induced a biphasic oxidative burst in localtreated tissue, leading to the generation of superoxide anion $\left(\mathrm{O}_{2}^{--}\right)$ and hydrogen peroxide $\left(\mathrm{H}_{2} \mathrm{O}_{2}\right)$ (Fig. 1). Since ROS accumulation exhibited a low and transitory first phase and a stronger and longer second one, our results are in line with other studies reporting elicitors that induce this kind of biphasic oxidative burst in a variety of plant-pathogen interaction systems (Galletti et al. 2008; Kasparovsky et al. 2004; Lamb and Dixon 1997; Pauw et al. 2004; Torres et al. 2006). It is a well-known fact that $\mathrm{Ca}^{2+}$ influx from extracellular spaces and changes in cytosolic concentration are crucial steps in the signaling cascade leading to the activation of MAPKs and HR (Garcia-Brugger et al. 2006; Lecourieux et al. 2002). In the current study, we demonstrated that AsES induced an early $\mathrm{Ca}^{2+}$ influx in strawberry leaves $1 \mathrm{hpt}$ (Fig. 2), which overlapped with the early ROS burst (Fig. 1). This result is in agreement with a previous study in which intracellular $\mathrm{Ca}^{2+}$ was accumulated in mesophilic rice cells after Magnaporthe grisea infection and it was essential for subsequent ROS production (Kuta and Gaivaronskaya 2004). Furthermore, there are some reports about elicitors triggering early transient $\mathrm{Ca}^{2+}$ influx and its apoplastic accumulation, such as cryptogenin in cell suspensions of Nicotiana plumbaginifolia (Lecourieux et al. 2002).

The HR is a rapid, local defense-related programmed cell death triggered by microbial pathogens and by a variety of
A

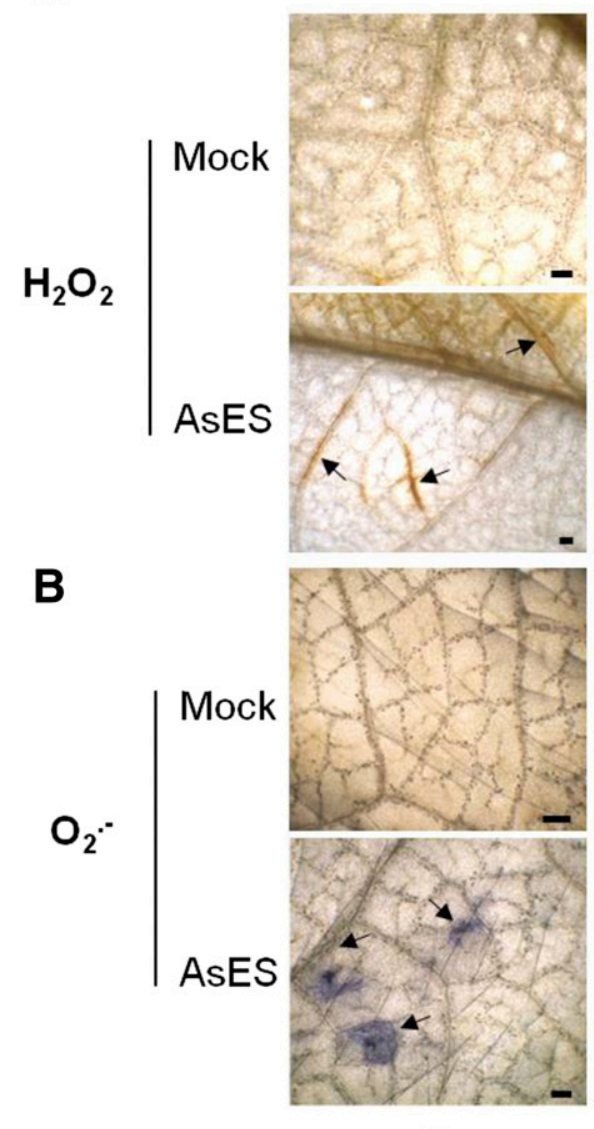

2
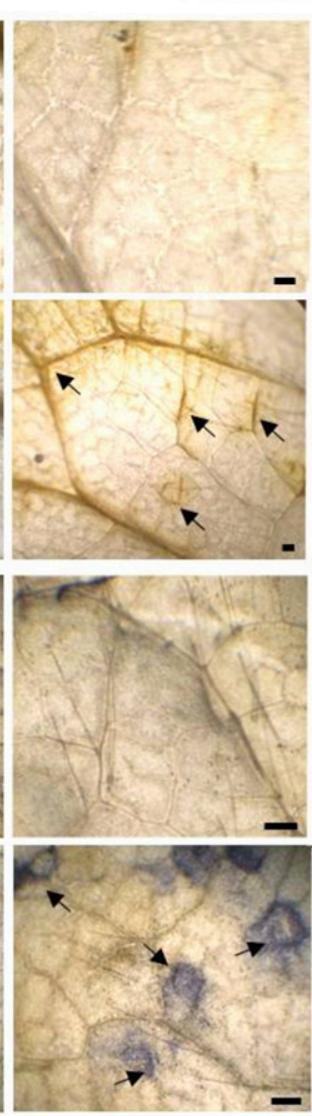

4

\section{Proximal leaflet}
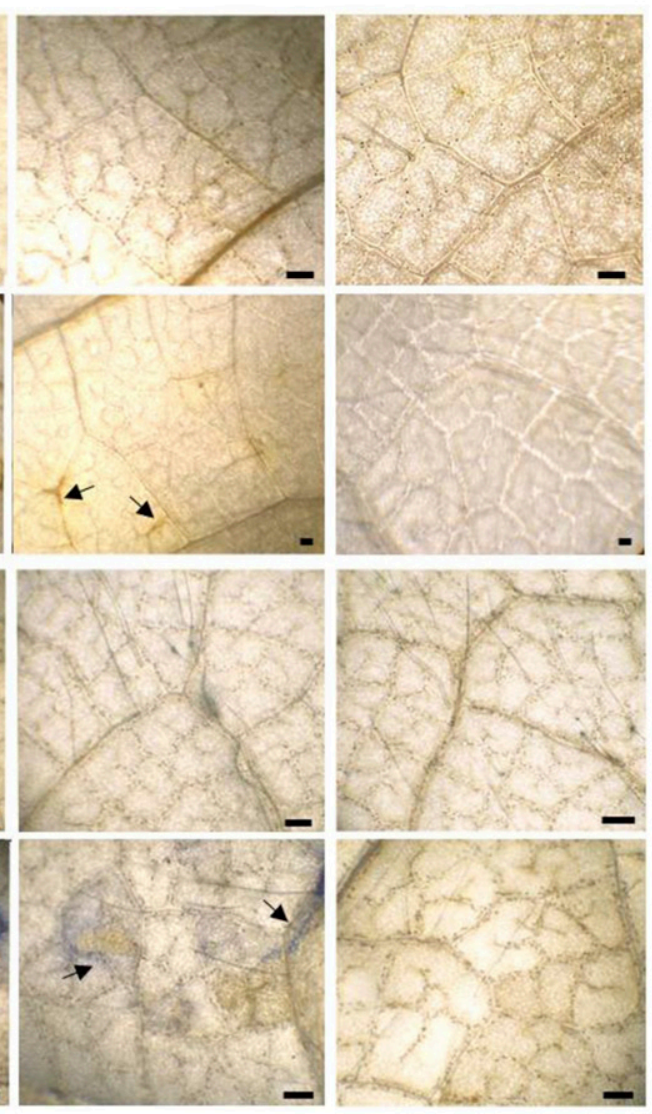

6

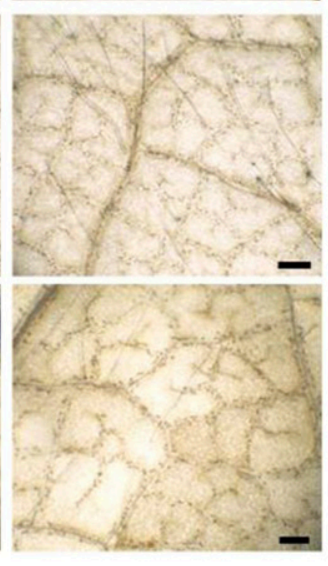

12

Hours post treatment

Fig. 4. AsES induces systemic micro-oxidative bursts in proximal leaflets. A, Accumulation of hydrogen peroxide $\left(\mathrm{H}_{2} \mathrm{O}_{2}\right)$, and $\mathbf{B}$, superoxide anion $\left(\mathrm{O}_{2}^{\cdot-}\right)$ was analyzed in nontreated proximal leaflets from mock- and AsES-infiltrated leaves 2, 4, 6, and $12 \mathrm{~h}$ posttreatment. $\mathrm{H}_{2} \mathrm{O}_{2}$ and $\mathrm{O}_{2}^{--}$were visualized by 3,3'diaminobenzidine and nitroblue tetrazolium staining methods, respectively. Brownish and blue deposits were indicative of $\mathrm{H}_{2} \mathrm{O}_{2}$ and $\mathrm{O}_{2}^{--}$accumulation, respectively, and are indicated by arrows. Three independent assays were performed $(n=5)$ with similar observations. One representative image is used to illustrate results of each treatment. Bars $=100 \mu \mathrm{m}$. 
elicitors (Chisholm et al. 2006; Deslandes and Rivas 2012; Greenberg et al. 1994; Heath 2000; Jones and Dangl 2006; Koornneef and Pieterse 2008). There are some characteristic plant defense responses related to HR, such as ROS burst, necrosis, and cytoplasm shrinkage, among others, generally accompanied by production of autofluorescence (Greenberg and Yao 2004; Heath 1998; Lam et al. 2001; Mur et al. 2008; van Doorn et al. 2011). In agreement with HR signaling and symptoms, we demonstrated that the elicitor AsES induced a macroscopic necrotic lesion in ILs (Fig. 3A), which was temporally and spatially associated with the appearance of autofluorescence (Fig. 3B) and was preceded by ROS production (Fig. 1). Moreover, yellow autofluorescence correlated with the initial stages of necrosis, while green fluorescence correlated with the advanced ones, suggesting that the nature of autofluorescent compounds changed during the necrotizing process (Fig. 3). We therefore conclude that it is highly likely that the AsES-induced ROS burst leads to a necrotic-like HR, as has been described to occur in many other plant-pathogen interactions (Sagi and Fluhr 2001). ROS and HR are two plant defense mechanisms closely related to each other, that induce cell death after plants are attacked by (hemi)biotrophic pathogens (Bethke and Jones 2001; Dat et al. 2003; Glazebrook 2005). Hence, it is plausible that AsES could induce these responses as a direct protective effect in order to halt the infection of the fungus C. acutatum, as was previously demonstrated by Chalfoun et al. (2013). However, induction of ROS and HR would not be effective defense responses against necrotrophs, such as $B$. cinerea, since these pathogens make use of ROS and HR for their own benefit (Choquer et al. 2007; Govrin and Levine 2002; van Kan 2006;
Williamson et al. 2007). Thus, rather than being a defense mechanism per se, in this case, AsES-induced ROS would lead to cell death to help to either release signals, allow the delivery of defensive compounds into surrounding healthy cells, or both, in order to alert them of the attack and trigger other defense responses effective against necrotrophic invaders. Moreover, since ROS was shown to be induced by a soft mechanical stimulus in Arabidopsis that was effective to trigger protection toward $B$. cinerea (Benikhlef et al. 2013), it cannot be ruled out that the AsES-induced ROS burst described in this study could also participate in protection of strawberry plants against $B$. cinerea and other necrotrophic pathogens. Taken together, these results indicate that it is possible that the defense response induced by the elicitor AsES can provide protection against pathogens with different lifestyles.

Regarding the appearance of autofluorescence within the AsES-induced necrotic area, evidence shows that it could, at least partly, be due to the accumulation of soluble and cell wall-bound PCs as they were found to be significantly increased $72 \mathrm{hpt}$, coinciding with maximum autofluorescence detection (Fig. 3). This result is in agreement with previous studies in which apposition of fluorescent materials such as PCs occurred upon pathogen infection or elicitor induction (Freytag et al. 1994; Graham and Graham 1991; Heath 1998; McLusky et al. 1999; Nicholson and Hammerschmidt 1992; Skalamera and Heath 1998; Wang et al. 2015) and in which cells undergoing HR appeared autofluorescent (Greenberg et al. 1994; Heath 2000; Koga et al. 1988). Taken together, all these data let us speculate that AsES triggers ROS and PC production or release from cells, which become autofluorescent and, finally, undergo cell death.

\section{Proximal leaflet}

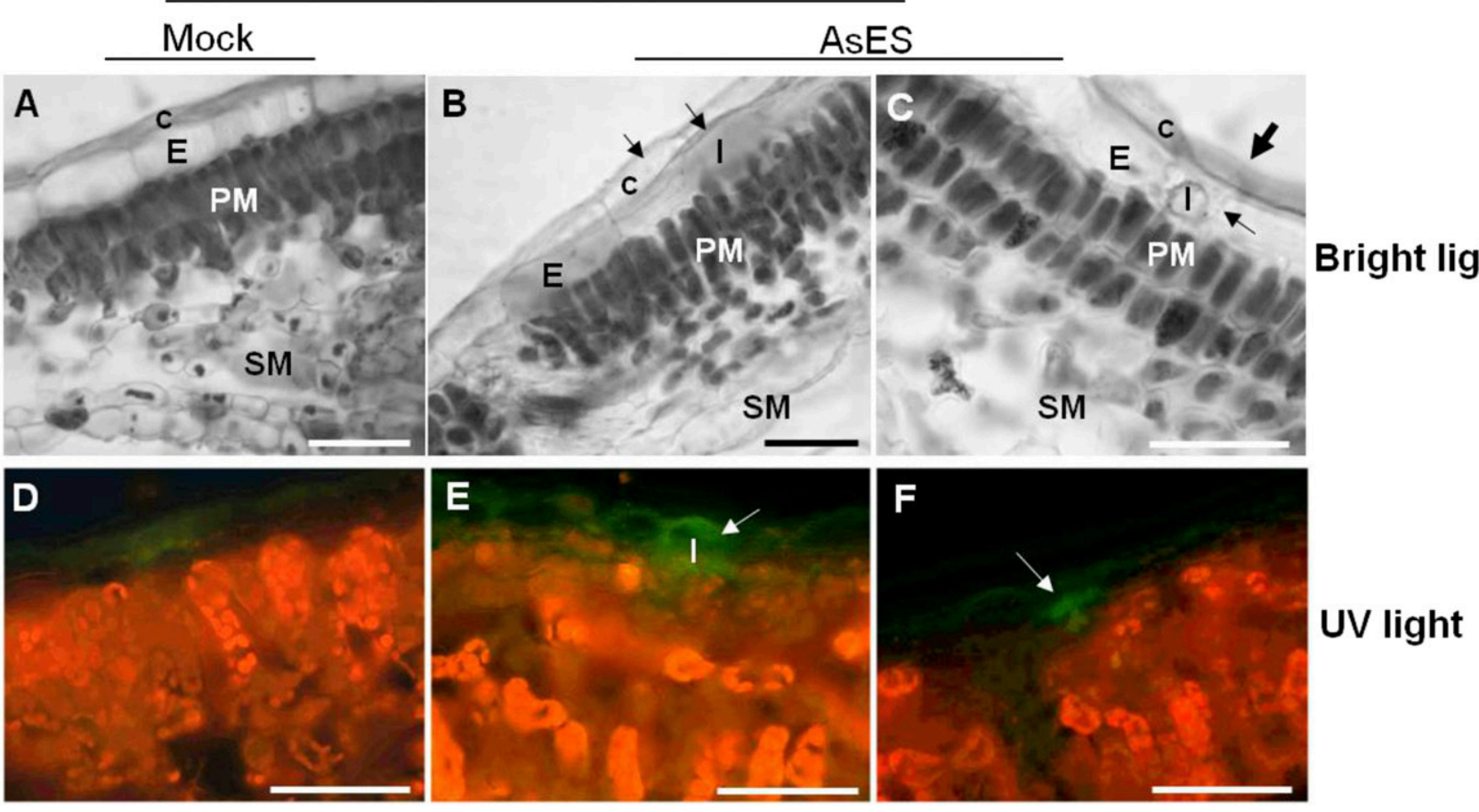

Fig. 5. AsES induces morphological and anatomical changes in cells undergoing micro hypersensitive cell-death responses (micro-HRs) in proximal leaflets. Histological transverse sections of proximal leaflets (PL) from mock- and AsES-infiltrated plants were observed under bright and UV light 4 h posttreatment. A, Under bright light, PL tissues in mock- and B, AsES-infiltrated plants, in which cells from cuticle and adaxial epidermis are enlarged (arrows). C, Collapsed idioblast among epidermal cells (thin arrow) and released intracellular content observed as a diffuse layer on the cuticle (thick arrow). D, Under UV light, cuticle and epidermal cells from mock-infiltrated plants presented a basal green autofluorescence, whereas E, in AsES-infiltrated plants, an enlarged epidermal idioblast is distinguished due to strong green autofluorescence (arrow) and F, a collapsed idioblast appears as diffuse green autofluorescence (arrow). $\mathrm{c}=$ cuticle, $\mathrm{E}=$ epidermis, $\mathrm{PM}=$ palisade mesophyll, $\mathrm{SM}=$ spongy mesophyll, and $\mathrm{I}=$ idioblast. Three independent assays were performed $(n=20)$ with similar observations. One representative picture is used for illustration of each treatment. Bars $=100 \mu \mathrm{m}$. 
AsES-induced SAR is characterized by microbursts, micro-HRs, cell-wall reinforcement,

and SA accumulation.

In previous works, we have reported that the protection exerted by AsES toward $C$. acutatum (Chalfoun et al. 2013) and $B$. cinerea (Hael-Conrad et al. 2015) is systemically induced. Thus, in an attempt to characterize the systemic response, ROS burst and HR formation were analyzed in untreated PLs and DLs. Although no macroscopic changes were observed in PLs and DLs, these cells underwent micro-oxidative bursts with production of $\mathrm{O}_{2}^{--}$and $\mathrm{H}_{2} \mathrm{O}_{2}$ (Figs. 4 and 6). Similarly to what was described in Arabidopsis plants challenged with Pseudomonas spp. (Alvarez et al. 1998), these microbursts appeared as low-frequency secondary oxidative bursts occurring systemically in proximal and distal strawberry leaflets, predominantly associated with veins, and visualized in small cell clusters. In addition, they first occurred in PLs and, later, in DLs, suggesting a systemic time-dependent dissemination of this response.

HR has previously been reported not to be restricted only to cells physically invaded by a pathogen (Heath 2000), which prompted us to study the possible occurrence of this response in systemic tissue in AsES-treated strawberry plants. When analyzing PLs from AsES-infiltrated plants, we found that cuticle and epidermis cells underwent important morphological and anatomical changes, such as cytoplasm shrinkage or cellular volume increase (Fig. 5). These cells, described as idioblasts, were found not only to swell and later burst but also became autofluorescent, possibly associated with accumulation of PCs (Fig. 5E, F). As a consequence, discrete autofluorescent bursts occurred, generating few death cells that were associated to systemic micro-HRs. Interestingly, micro-HRs were also observed to occur in DLs of AsES-infiltrated plants, in which were observed microscopic necrotic spots originating in small clusters of cells, some of which appeared to be autofluorescent while others appeared as empty black spots after hutching (Fig. 6H and I). We also observed that the micro-HRs presented a similar distribution pattern as the oxidative microbursts, which occurred predominantly around veins $\left(\mathrm{H}_{2} \mathrm{O}_{2}\right)$ (Fig. 6B) or among them $\left(\mathrm{O}_{2}^{--}\right)$(Fig. 6E). These results show that the oxidative burst and hypersensitive cell death were not confined to the infiltration site but were spread toward systemic tissues at discrete micro sites. Even though micro-HRs have been described previously by many authors in different plant-pathogen interaction systems (Dat et al. 2003; Hoeberichts and Woltering 2003; Lam 2004; Li et al. 2006; Sasabe et al. 2000), this is, to our knowledge, the first time to described in response to a fungal elicitor molecule.

It is a well-known fact that SA plays a fundamental role in SAR in plants (Delaney et al. 1994; Gaffney et al. 1993; Klessig

\section{Distal leaflet}

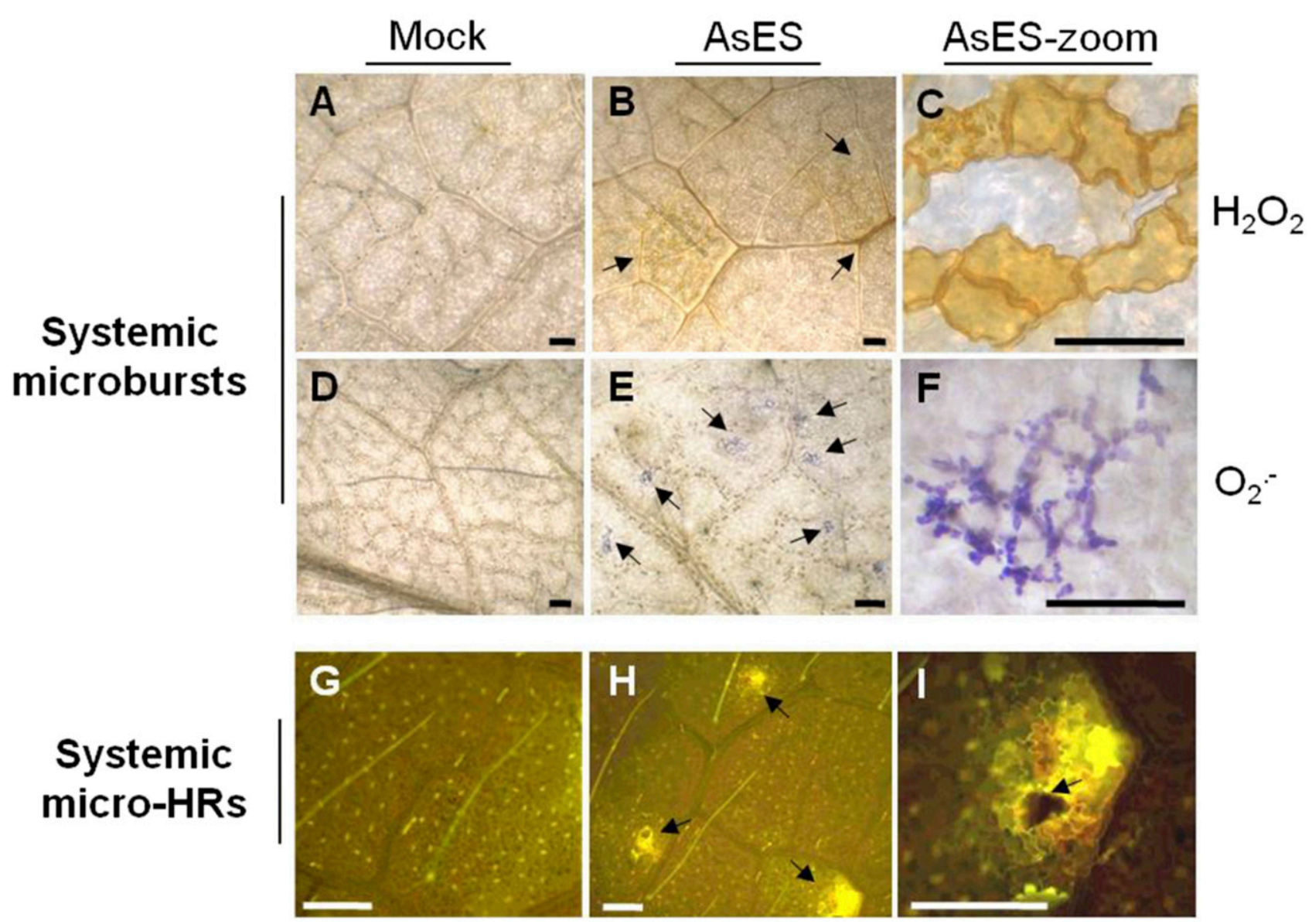

Fig. 6. AsES induces systemic microbursts and micro hypersensitive cell-death responses (micro-HRs) in distal leaflets. A to F, Nontreated distal leaflets (DL) from mock- and AsES-infiltrated plants were analyzed for oxidative microbursts and micro- $\mathrm{HR}$ occurrence at $24 \mathrm{~h}$ posttreatment. Accumulation of $\mathrm{H}_{2} \mathrm{O}_{2}$ and $\mathrm{O}_{2}^{*-}$ was analyzed by $3,3^{\prime}$-diaminobenzidine and nitroblue tetrazolium staining methods. Brownish and blue deposits were indicative of $\mathrm{H}_{2} \mathrm{O}_{2}$ and $\mathrm{O}_{2}^{\cdot-}$ accumulation, respectively, and are indicated by arrows. G to I, Necrosis within micro-HR sites was visualized in vivo under UV light. Punctual brilliant spots indicate small cell clusters of the abaxial epidermis undergoing micro-HR (H, arrows) and a collapsed cell was visualized as a black hole (I, arrow). Three independent experiments were performed $(n=5)$ with similar observations. One representative image is used to illustrate results of each treatment. Bars $=100 \mu \mathrm{m}$. 
et al. 2000; Malamy et al. 1990; Mauch-Mani and Métraux 1998; Métraux et al. 1990; Ryals et al. 1996). Here, we demonstrated that SA-dependent signaling is likely to participate in AsES-triggered defense response in strawberry, since the elicitor induced a noticeable transient accumulation of SA at an early stage after treatment (Fig. 7). Interestingly, SA was extracted from the phloem sap of petioles, suggesting a possible initial synthesis in local-treated leaflets and, thereafter, translocation to other parts of the plant through the phloem. This finding is striking, since it has been largely demonstrated in Arabidopsis and tobacco that SA is not the systemic signal in SAR and, thus, is not translocated via the phloem (An and Mou 2011; Durrant and Dong 2004; Fu and Dong 2013). Our result opens up the possibility of SA transportation and signaling via

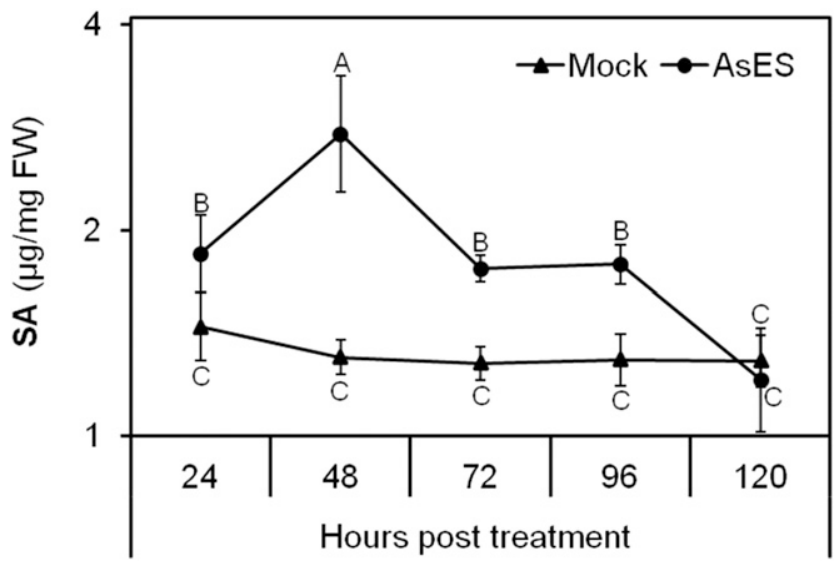

Fig. 7. AsES induces salicylic acid (SA) accumulation in strawberry plants. Total SA was extracted from phloem sap collected from petioles of mock- and AsES-treated plants, was purified by high performance liquid chromatography and was quantified by fluorescence. Mean values \pm standard error are represented from one typical assay $(n=6)$. Analysis of variance followed by a least significant difference test was performed, using InfoStat/L software. Different letters represent statistically significant differences $(P<0.05)$. Two independent assays were performed with similar results. the phloem in strawberry as a response to AsES treatment leading to SAR development. In a recent study on defense responses triggered by AsES in Arabidopsis, it was shown that AsES-induced SA accumulation occurred in local-treated leaves; yet, it was not quantified from phloem sap (Hael-Conrad et al. 2015). Further studies are necessary to better elucidate the SA systemic defense signaling network occurring in strawberry plants. Nevertheless, we are able to conclude that SA does participate during AsES-induced SAR in strawberry.

Cell-wall strengthening contributes to the innate immune response in strawberry plants when challenged with a pathogen (Amil-Ruiz et al. 2011). In the present study, we observed that AsES induced callose and lignin depositions in strawberry plants in a time-dependent manner (Fig. 8). In agreement with these results, other authors have observed callose deposition in strawberry plants upon treatment with plant growth-promoting bacteria (Tortora et al. 2012) and an avirulent pathogen (Salazar et al. 2007). In PLs of an AsES-IL, accumulation of both polymers was detected $12 \mathrm{hpt}$, while in DLs, they were observed after $7 \mathrm{dpt}$, demonstrating that this response occurs much later in distal leaves.

\section{AsES induces the expression a wide spectrum of defense-related genes.}

The idea that the elicitor AsES induces local defense responses based on the induction of early events like calcium influx, ROS, necrotic-like HR, and autofluorescent compounds in ILs as well as systemic responses evidenced by oxidative microbursts, micro-HRs, cell-wall fortification, and accumulation of SA in nontreated leaflets is further reinforced by the fact that expression of several genes associated with such defense responses in strawberry are up-regulated in elicitor-treated plants.

AsES significantly induced FaPRl expression in a two-peak profile first between 72 and $96 \mathrm{hpt}$ and, then, between 144 and $168 \mathrm{hpt}$ (Fig. 9A), suggesting its participation in AsES-induced defense response, playing a possible central role in defense against pathogens, as has been amply reported for PR proteins (Graham et al. 2003; Jones and Dangl 2006; Van Loon 1997). Since SA was significantly accumulated earlier than FaPRI
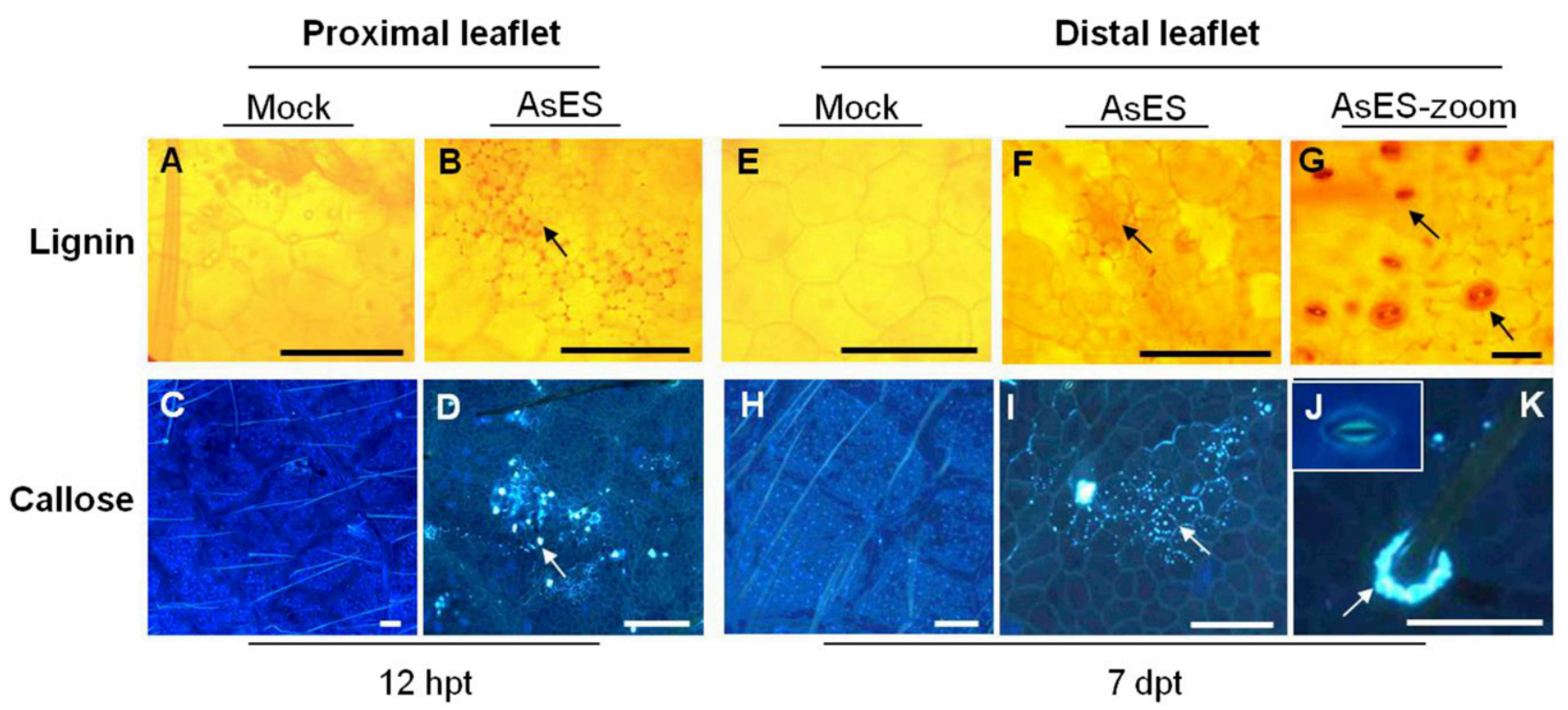

Fig. 8. AsES induces cell-wall reinforcement in proximal and distal leaflets. A to D, Nontreated proximal and $\mathbf{E}$ to $\mathbf{K}$, distal leaflets from mock- and AsESinfiltrated plants were analyzed for lignin and callose depositions $12 \mathrm{~h}$ posttreatment (hpt) and 7 days posttreatment (dpt), respectively. Lignin was analyzed with safranin-O, whereas callose deposition with aniline blue staining methods. Black arrows indicate lignin deposits in the wall of mesophyll cells from the adaxial epidermis (B, F) and stomatal guard cells from the abaxial epidermis (G). White arrows indicate callose in cells from adaxial epidermis (D, I), stomatal guard cells $(\mathrm{J})$ and cells forming the base of a trichoma $(\mathrm{K})$. Three independent assays were performed $(n=5)$ with similar observations. One representative image is used to illustrate results of each treatment. In A, B, E to G, and I to K, bars $=40 \mu \mathrm{m}$; in $\mathrm{C}$, D, and $\mathrm{H}$, bars $=100 \mu \mathrm{m}$. 
upregulation, it is likely that there is a correlation between both signals, suggesting that FaPRl expression is a consequence of SA accumulation, as has been reported before (An and Mou 2011; Chaturvedi and Shah 2007; Durrant and Dong 2004). In line with our results, Grellet-Bournonville et al. (2012) demonstrated that FaPRl expression correlated with SA accumulation upon challenge with an avirulent pathogen in strawberry. In addition, expression of FaPRl was shown to be induced when plants were treated with exogenous SA, confirming a close relationship between SA accumulation and $F a P R l$ gene expression in strawberry (Grellet-Bournonville et al. 2012). In an attempt to explain whether the decrease in SA accumulation 72 and $120 \mathrm{hpt}$ was due to the action of known enzymes in charge of removing the phytohormone in plants, gene expression analysis of SA glycosyltransferase ( FaSAGT) and SA methylesterase (FaSAMES) was performed. SA glycosyltransferase converts SA to its glycosylated forms (salycilic acid glycolylate and salycilic acid glycosylester), and SA methylesterase hydrolysates methyl salicylate into active free SA in distal tissues. Although no significant expression changes of these enzymes were detected, their participation should not be completely ruled out and more analyses should be done in order to properly address this issue.

FaPG1 gene expression was significantly up-regulated by AsES (Fig. 9B). This gene codifies for a cell wall-degrading polygalacturonase, suggesting its participation in some AsESinduced defense mechanism. It has been reported that PG1 participates in the metabolism of pectin, producing oligogalacturonides (OGs) that may act as DAMPs able to elicit different cellular responses during plant-pathogen interactions in strawberry (Osorio et al. 2011). Thus, we may speculate that AsES signaling could be amplified by the generation of OGs.
Plants generate apoplastic ROS mainly through plasma membrane-bound NADPH oxidases $(\mathrm{RBOH})$ and cell wallbound peroxidases (Bolwell et al. 2002; Grant et al. 2000; Torres and Dangl 2005). In Arabidopsis, RBOH enzymes are encoded by a family of ten genes, among which AtRBOH-D and AtRBOH-F are the principal enzymes involved in stress responses (Torres and Dangl 2005). Here, we evidenced that a $F a R B O H-D$ orthologous gene, which codifies for the main enzyme responsible for ROS production in Arabidopsis (Morales et al. 2016; Torres et al. 2002 2006), was markedly upregulated by AsES in strawberry (Fig. 9C). The fact that the observed oxidative burst in strawberry plants treated with AsES occurred earlier than the induced expression of $\mathrm{FaRBOH}-\mathrm{D}$ (Figs. 1 and 9C) can be explained if the participation of pre-existing $\mathrm{RBOH}$ as well as cell-wall peroxidases is considered. On the other hand, $\mathrm{RBOH}-\mathrm{F}$ has been shown to induce an HR response as a consequence of a previous oxidative burst in Arabidopsis (Torres and Dangl 2005; Torres et al. 2002, 2006). In strawberry AsES induced upregulation of a FaRBOH-F orthologous gene (Fig. 9D), suggesting that this enzyme may endorse ROS production as well as HR induction. Interestingly, Morales et al. (2016) found that PAMP-like elicitors such as chitin, flg22, and elf18 induced the expression of $R B O H-D$ promoter but not of $R B O H-F$ in Arabidopsis transgenic seedlings carrying the $R B O H-D$ or $R B O H-F$ promoter fused to $\beta$-glucuronidase reporter gene.

MYB30 is a positive regulator of the signaling pathway controlling the establishment of cell death in response to pathogen attack in Arabidopsis (Canonne et al. 2011; Daniel et al. 1999; Froidure et al. 2010; Vailleau et al. 2002). The upregulation of a FaMYB30 orthologous gene in $F$. ananassa (Fig. 9E) suggests its participation during AsES-induced HR.
A

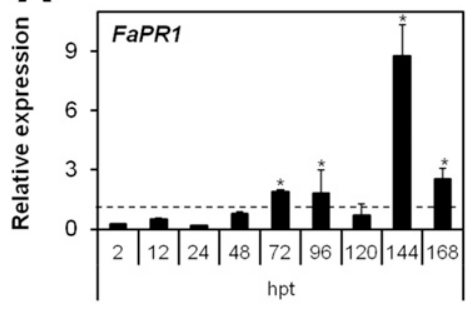

D

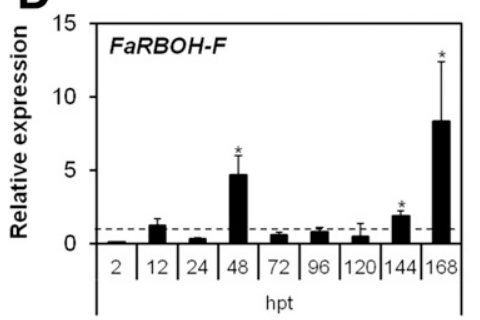

G

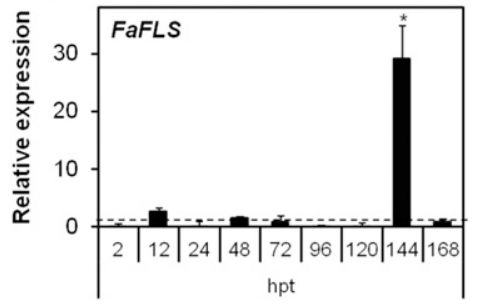

B

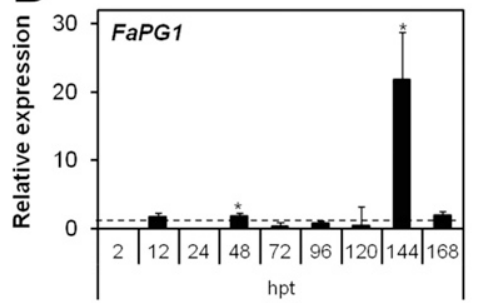

E

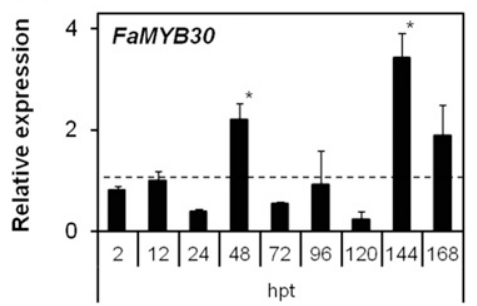

H

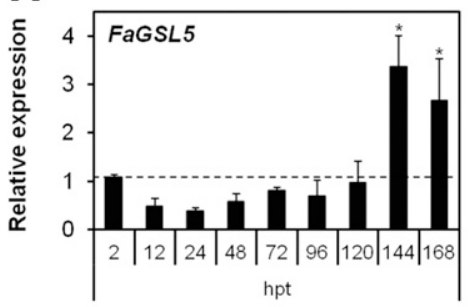

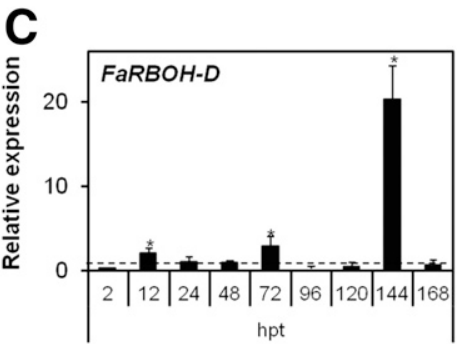

$\mathbf{F}$
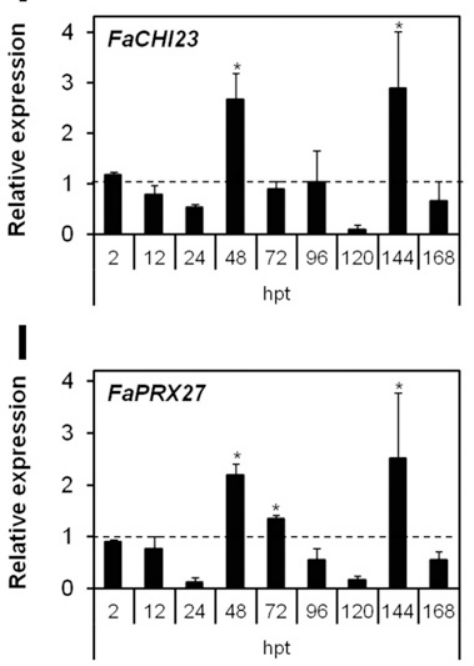

Fig. 9. Quantitative polymerase chain reaction (qPCR) analysis of defense-related genes in strawberry plants. A to D, The expression of marker genes was determined in proximal and $\mathbf{E}$ to $\mathbf{K}$, distal leaflets in mock- and AsES-treated plants 2, 12, 24, 48, 72, 96, 120, 144, and 168 h posttreatment (hpt). All values were normalized with respect to the constitutive expression of the internal reference gene $F a E F-1 \alpha$ and are expressed related to the mock values at each time. Bars represent mean values \pm standard error from two biological replicates with three technical replicates for each qPCR reaction $(n=6)$. Asterisks indicate a statistically significant difference between gene expression in mock- and AsES-treated plants, calculated by fgStatistics software $(P<0.05)$. 
A set of defense responses is activated rapidly in cells undergoing HR, like secondary metabolic pathways such as the branched phenylpropanoids, which produces a great battery of antimicrobial PCs (Dixon and Lamb 1990; Hammond-Kosack and Jones 1996). AsES treatment resulted in chalcone isomerase FaCHI23 induction, suggesting, on one hand, the activation of the phenylpropanoid pathway and, on the other, the specific participation of flavones and isoflavones (Fig. 9F). Likewise, the elicitor induced the expression of the flavonol synthase FaFLS (Fig. 9G), adding more evidence of activation of the phenylpropanoid pathway and, more specifically, of flavonoides biosynthesis. Quercetin, kaempferol, and myricetin are examples of antimicrobial flavonols that may have a defensive function in strawberry leaves against pathogens upon AsES induction.

In addition, the phenylpropanoid pathway includes the callose and lignin branches, whose activation was analyzed by studying the expression of FaGSL5 and FaPRX27 genes, respectively. GSL5 is a key enzyme for callose synthesis in higher plants, as demonstrated with Arabidopsis gsl5 mutants, which became susceptible to avirulent pathogens (Jacobs et al. 2003). In strawberry, the FaGSL5 gene was up-regulated by elicitor treatment (Fig. 9H) and is, therefore, likely to be an active part of AsES-induced defense response. However, since there is no time correlation between the induced expression of this gene and callose deposition, it is likely that other genes involved in callose synthesis or deposition, or both, may also be participating, as well as pre-existing GSL5. Lignin polymerization is regulated by class III peroxidases, which are induced upon different stimuli such as biotic stress (Lüthje et al. 2011; Mathé et al. 2010; Valério et al. 2004; Zhong and Ye 2009). Specifically, PRX27 encodes a functional enzyme that is required for the polymerization of phenylpropanoids in ripening of strawberry fruit during lignin formation but not in foliar tissue (Ring et al. 2013). In this study, however, we demonstrated that FaPRX27 was induced in strawberry leaves upon AsES treatment (Fig. 9I). This data suggests that this peroxidase should participate in the AsES-induced defense response by catalyzing the cross-linking of monolignols in the cytosol helping in the final formation of lignin.

Finally, taking into account all genes analyzed, we observed that a regular pattern emerges with an incipient but significant upregulation $48 \mathrm{hpt}$ and a higher induction $144 \mathrm{hpt}$, suggesting an initial activation of defense mechanisms that becomes stronger over the time. These findings could be further explained in terms of AsES-induced protection against C. acutatum in strawberry, because it was demonstrated that, upon AsES treatment, the plant needed a minimum time of $168 \mathrm{~h}$ ( 7 days) to fully activate its innate immune defenses to completely halt fungal infection (Chalfoun et al. 2013).

\section{How does AsES behave like? PAMP or effector? Or does it trigger DAMP generation?}

Although more investigation is required to answer the question about whether AsES behaves as a PAMP, a DAMP, or an avirulent-pathogen effector, we are tempted to speculate that AsES is an original molecule that shows features found in both type of elicitors. As a PAMP because it acts ubiquitously, activating defense responses not only in different strawberry cultivars of $F$. ananassa, such as Milsei Tudla, Camarosa, and Pájaro (Chalfoun 2009; Chalfoun et al. 2013), but also in other species of strawberry, like the wild $F$. vesca (unpublished data). In addition, it was recently reported that AsES possess effective defense-inducing activity in different genera, such as Arabidopsis (Hael-Conrad et al. 2015). Noteworthy, AsES is also active against pathogens with different lifestyles, such as the hemibiotrophic $C$. acutatum fungus, causal agent of anthracnose in strawberry (Chalfoun et al. 2013), and the necrotrophic fungal pathogen $B$. cinerea, causal agent of gray mold disease (Hael-Conrad et al. 2015). With these pieces of evidence, it is, therefore, highly unlikely that the gene-to-gene resistance model is valid for AsES (Flor 1971).

Nevertheless, AsES behaves like an avirulent-pathogenic effector because, as described in the zig-zag model of Jones and Dangl (2006), it induces a HR response, activating an ETI. We may further speculate that AsES could induce the generation of DAMPs, since its proteolytic activity is essential for activating defense mechanisms and confer protection in strawberry plants (Chalfoun et al. 2013) and other plant species (data not shown). If the latter hypothesis is true, we should anticipate that the real defense inductor is a molecule originated from the proteolytic activity of AsES through the processing of a plant cellular component rather than AsES per se. Currently, work is being focused on determining AsES receptor or target molecule and structure in plant.

\section{Conclusion.}

The present work describes the defense mechanisms induced in strawberry plants upon AsES treatment, indicating that the novel elicitor subtilisin-like protein induces a complex signaling network that involves both LAR and SAR. It is the first study to report the induction of microbursts and micro-HRs upon elicitor treatment in strawberry. The wide spectrum of defense responses described can, at least partly, explain AsES capacity to protect against pathogens of opposite lifestyles, like hemibiotrophic and necrotrophic fungi. This characteristic of AsES-induced resistance makes it an almost ideal candidate as a biocontrol agent in order to control anthracnose and gray mold diseases in strawberry. Ongoing studies are directed to determine whether AsES could also be applied to other crops in order to improve their defense against economically important plant diseases.

\section{MATERIALS AND METHODS}

\section{AsES purification.}

AsES elicitor protein was purified from the supernatant of 21-day static liquid culture of Acremonium strictum SS71 (The Leibniz Institute DSMZ accession number DSM 24396) as previously described (Chalfoun et al. 2013). Briefly, the fractionation procedure included an ultrafiltration step (cut-off $30 \mathrm{kDa}$ ), followed by two steps of chromatographic separation in fast protein liquid chromatography, first by anionic exchange (Q-Sepharose, $\mathrm{pH} 7.5$ ), and then, by hydrophobic interaction (Phenyl-Sepharose). AsES purity was confirmed by twodimensional-polyacrylamide gel electrophoresis and C18-high performance liquid chromatography, as described previously (Chalfoun et al. 2013). Finally, the purified protein was lyophilized and was kept at $4^{\circ} \mathrm{C}$ until use. When necessary, it was dissolved at the indicated concentration in distilled sterile water and was kept at $-20^{\circ} \mathrm{C}$. Proteolytic activity of AsES protein was measured by enzymatic hydrolysis of the chromogenic peptide N-succinyl-Ala-Ala-Pro-Phe-p-nitroanilide (Suc-AAPF-pNA; Sigma), as described previously (Chalfoun et al. 2013), and was quantified according to Moallaei et al. (2006).

\section{Plant material.}

Plants of strawberry (Fragaria $\times$ ananassa Duch.) cv. Pájaro used in the assays were obtained from the Strawberry Active Germplasm Bank (BGA) at the National University of Tucumán (Tucumán, Argentina) and in vitro propagated. Briefly, meristematic tissue of healthy plant runners was implanted and multiplied in MS medium (Sigma) (Murashige and Skoog 1962) and was rooted in pots with a sterilized soil mix of humus and perlite (2:1). Plants were grown in a 16-h light cycle (white fluorescent light, $350 \mu \mathrm{mol}$ photons $\mathrm{m}^{-2} \mathrm{~s}^{-1}$ ) with $70 \%$ relative humidity and a temperature of $28^{\circ} \mathrm{C}$. Plants 12 to 15 weeks old were used for all assays described in this work. 


\section{AsES treatment by infiltration.}

The central leaflet of the youngest totally expanded trifoliate leaf in each plant was mock- or AsES-infiltrated (AsES-IL). The untreated lateral leaflets of the infiltrated leaf correspond to PL; and the second youngest untreated trifoliate leaf was designated as "distal leaf" (PL). Twenty (20) microliters of AsES (60 nM) or distilled water (mock) were infiltrated at two points between the central nerve on the abaxial side of the leaflet, with the help of a $1 \mathrm{ml}$-syringe without needle. All treated plants were grown in a growth chamber under controlled conditions, as described above, until use.

\section{AsES treatment by spray.}

For biphasic ROS, SA quantification, and real time qPCR assays, leaves were sprayed to run-off with AsES (60 nM) or distilled water (mock) (corresponding to approximately $500 \mu \mathrm{l}$ per plant) and were kept in a growth chamber under controlled conditions until use.

\section{Oxidative burst.}

Accumulation of ROS was detected by specific in situ histochemical staining procedures. For hydrogen peroxide $\left(\mathrm{H}_{2} \mathrm{O}_{2}\right)$, 3,3'-diaminobenzidine (DAB), according to Thordal-Christensen et al. (1997), and for superoxide ion $\left(\mathrm{O}_{2}^{-}\right)$, nitroblue tetrazolium (NBT), according to Doke (1983), were used. Mock- and AsES-IL, PL, and DL were harvested at different hours posttreatment, as stated in figure legends, and were stained with DAB or NBT. Leaflets were microscopically analyzed and images were taken with a digital camera attached to microscope with bright field settings (BH2-RFC, Olympus). For the biphasic ROS accumulation assay, quantification of brownish and blue deposits was carried out using ImageJ software, and an area value was obtained. Results were expressed as relative area between AsES- and mock-treated leaflets: area of brownish/blue deposits (AsES-treated plants) $/$ area of brownish/blue deposits $_{\text {(mock-treated plants). }}$. For all assays, one leaflet from each of five plants was used per treatment $(n=5)$. Two or three independent experiments were performed.

\section{Calcium determination.}

Accumulation of intracellular calcium was observed in leaf discs according to Hirst et al. (1999), with some modifications made in our laboratory. Briefly, $5 \mathrm{~mm}$ in diameter discs were obtained from the youngest totally expanded leaf and were submerged in 1,000 $\mu \mathrm{l}$ of a solution of $10 \mu \mathrm{M}$ Fura 2-AM probe (Invitrogen) dissolved in modified W5 buffer $(154 \mathrm{mM} \mathrm{NaCl}$, $5 \mathrm{mM} \mathrm{KCl}, 125 \mathrm{mM} \mathrm{CaCl}_{2}, 0.5 \mathrm{M}$ sacarose, and $2 \mathrm{mM}$ morpholineethanesulfonic acid; $\mathrm{pH}$ 5.6). Then, five vacuum pulses were applied, and disks were kept in darkness for $30 \mathrm{~min}$, were rinsed twice with distilled water, and were suspended in W5 buffer. Thereafter, disks were mock- and AsES-treated and were observed under fluorescence microscopy (BH-FRC, Olympus) set with an IB filter. Images were taken with a digital camera attached to the microscope. The presence of calcium was determined qualitatively as green areas on the leaf tissue visualized under fluorescent field. Two leaf disks of each of five plants were used for the assay $(n=10)$. Ten independent assays were performed.

\section{Autofluorescence and necrosis.}

Mock- and AsES-ILs and DLs were harvested at different hours posttreatment, as stated in figure legends, and were mounted between slide and cover slips for in vivo observations. For autofluorescence detection, samples were observed under UV light (329 nm) in a fluorescence microscope (BX51 U-LH 100HG, Olympus), whereas DLs were examined at $24 \mathrm{hpt}$ in a microscope with reflected light fluorescence attachment
(BH2-RFC, Olympus). For necrosis detection, ILs were observed in a microscope with bright field settings (BH-2, Olympus). Images were taken with a digital camera attached to each microscope. One leaflet from each of five plants was used per treatment $(n=5)$. Three independent assays were performed.

\section{Quantification of PCs.}

Soluble and cell wall-bound PCs were quantified in mockand AsES-ILs 24, 72, and 168 hpt. Leaflets were harvested, pooled, and weighed and were immediately frozen at $-20^{\circ} \mathrm{C}$ until use. For soluble PC extraction, vegetal tissue was resuspended in $80 \%$ methanol $(1 \mathrm{ml}$ per $100 \mathrm{mg}$ of $\mathrm{FW})$, gently agitated (100 rpm) for $12 \mathrm{~h}$ at $30^{\circ} \mathrm{C}$ in darkness, and then, centrifuged $(5,000 \times g)$ for $30 \mathrm{~min}$ at $4^{\circ} \mathrm{C}$. The extraction step was repeated once again. The corresponding leaf pellet was kept for $\mathrm{NaOH}$-hydrolyzable cell wall-bound PC determination, while both supernatants were combined and vacuumdried (Savant). Pellet obtained from combined supernatants was resuspended in $20 \%$ methanol at a final concentration of $0.5 \mathrm{~g}$ of leaf FW per milliliter (Hukkanen et al. 2007). The remaining leaf pellet was washed, first, with $80 \%$ methanol and, then, with $100 \%$ methanol to remove traces of residual soluble PCs. For hydrolysis, $1 \mathrm{ml}$ of $1 \mathrm{M} \mathrm{NaOH}$ per $20 \mathrm{mg}$ of dry material was added, and the tissue was incubated for $1 \mathrm{~h}$ at $70^{\circ} \mathrm{C}$. After centrifugation $(5,000 \times g)$ for $30 \mathrm{~min}$ at $4{ }^{\circ} \mathrm{C}$, the hydrolysate was acidified with a 1:10 volume of concentrated $\mathrm{HCl}$. PC content (phenolic and polyphenolic) of both extracts was determined using the Folin-Ciocalteu method according to Singleton et al. (1999). The amount of PC was expressed in gallic acid equivalents (GAE) per gram of FW from leaf tissue. Results were expressed as relative PC accumulation between AsES- and mock-treated leaves: PC (mg GAE/g FW) (AsES-treated leaves) $/ \mathrm{PC}$ (mg GAE/g FW) (mock- treated leaves). The central leaflet from each of five plants was harvested $(n=5)$ per treatment. Two independent assays were performed.

\section{Histological section preparation and microscopic observations.}

Histological sections were performed from PLs of mock- and AsES-infiltrated plants $4 \mathrm{hpt}$ to study morphological and anatomical changes during the cell-death process and to monitor the appearance of autofluorescence. For morphological studies, PLs were fixed in FAA (formalin-acetic acid-alcohol), and then, $10-$ to $15-\mu \mathrm{m}$ cross sections were obtained by free-hand cutting that were made transparent with $50 \%$ sodium hypochlorite, according to Dizeo de Strittmater (1973). Afterward, sections were washed six times with distilled water and were stained with safranin-O (Lucena et al. 2003). Finally, samples were mounted with $50 \%$ glycerol between slides and cover slips and were observed with a $40 \times$ objective lens under a microscope with bright field settings (BH-2, Olympus). For anatomical studies, histological sections from PLs were observed in vivo, using a fluorescence microscopy (BX51 U-LH 100HG, Olympus) set with a blue excitation filter (U-MWB2). For all assays, images were taken with a digital camera attached to each microscope. Twenty histological sections obtained from one leaflet of a single plant were used per treatment in both types of studies $(n=20)$. Observations in three independent assays were performed.

\section{Quantification of SA.}

SA was measured, as previously described (GrelletBournonville et al. 2012), by extracting phloem sap, using a micropipette from petioles of mock- and AsES-treated leaves. Samples were taken 24, 48, 72, 96, and $120 \mathrm{hpt}$, were pooled, and were immediately dispensed into $1 \mathrm{ml}$ of ice-cold absolute ethanol acidified with $\mathrm{HCl}(\mathrm{pH}$ 3.0). After the extraction 
procedure, SA was purified, as previously described (GrelletBournonville et al. 2012), by high performance liquid chromatography (Analytical HPLC, Gilson), using a C18 reversed phase column (Prodigy 5 ODS-2 Phenomenex) and was quantified by fluorometric determination at $\lambda_{\mathrm{ex}}=296 \mathrm{~nm}$ and $\lambda_{\mathrm{em}}=408 \mathrm{~nm}$, using a spectrofluorometer (Photon counting PC1, ISS). SA standard ( $>99.0 \%$ purity, Sigma) was used as internal control. The amount of SA was expressed in micrograms per milligram of sap FW. Extraction was performed from petioles from three leaves from each of six plants $(n=6)$ per treatment. Two independent assays were performed.

\section{Determination of callose and lignin deposition.}

Callose and lignin deposition was evaluated in PLs and DLs of mock- and AsES-infiltrated plants $12 \mathrm{hpt}$ and 7 days posttreatment (dpt), respectively. For callose determination, leaflets were stained with aniline blue, according to Yun et al. (2006). Briefly, leaflets were harvested and decolorized in a 3:1 ethanol 96\% and lactic acid mix (previously diluted 1:2 ethanol 96\%). The solution was changed several times until no chlorophyll was visualized. Translucent leaflets were rehydrated in $50 \%$ ethanol for $2 \mathrm{~h}$ and were then incubated in $67 \mathrm{mM} \mathrm{K}_{2} \mathrm{HPO}_{4}(\mathrm{pH} \mathrm{12})$ containing $0.01 \%$ aniline blue for $1 \mathrm{~h}$ at room temperature. For lignin determination, leaflets were stained with safranin-O, according to Lucena et al. (2003). Similarly, translucent rehydrated leaflets were incubated in $50 \%$ ethanol containing $0.01 \%$ safranin-O for $2 \mathrm{~min}$ at room temperature. Two $3-\mathrm{cm}$ segments for each stained leaflet were mounted on glass slides in $30 \%$ glycerol and were examined under a fluorescence microscope (BXS1 U-LH 100HG, Olympus) set with a blue excitation filter (U-MWB2). Images were taken with a digital camera attached to the microscope. One leaflet from each of five plants was used per treatment $(n=5)$. Three independent assays were performed.

\section{RNA extraction and qPCR analysis.}

Total RNA extraction was performed from the youngest totally expanded leaflet from each of three mock- or AsEStreated plants $(n=3)$. Leaflets were harvested 2, 12, 24, 48, 72, 96, 120, 144, and $168 \mathrm{hpt}$, were pooled and weighed, were immediately frozen in liquid nitrogen, were pulverized, and were kept at $-80^{\circ} \mathrm{C}$ until further use. RNA was isolated from $100 \mathrm{mg}$ of leaf tissue, using the RNAqueous-4PCR kit (Ambion). Next, total RNA was pretreated with DNase I (Thermo) in order to remove possible contaminating genomic DNA. RNA concentration and purity was measured using a spectrophotometer (Shimadzu BioSpec-mini UV-1280 UV-Vis), and then, $1 \mu \mathrm{g}$ of each sample was retro-transcribed into cDNA according to manufacturer's indications (Thermo). cDNA concentration was measured with spectrophotometer (BioSpec-mini UV-1280 UV-Vis, Shimadzu) and was adjusted to $25 \mathrm{ng} / \mu \mathrm{l}$ with sterile ultrapure water. For qPCR, the iQ supermix SYBR green was used (Bio-Rad), and reactions were performed in an ABI Prism 7500 real time PCR system equipment (Applied Biosystems): $0.1 \mu \mathrm{l}$ of each primer $(20 \mu \mathrm{M}), 2.0 \mu \mathrm{l}$ of cDNA $(25 \mathrm{ng} / \mu \mathrm{l}), 6.5 \mu \mathrm{l}$ of SYBR green, $4.3 \mu \mathrm{l}$ of sterile ultrapure water. The thermal profile was set to $95^{\circ} \mathrm{C}$ for $10 \mathrm{~min}$ (holding stage), 40 cycles of $95^{\circ} \mathrm{C}$ for $15 \mathrm{~s}$, and $60^{\circ} \mathrm{C}$ for $1 \mathrm{~min}$.

Expression of genes was estimated in relation to elongation factor-1a $(F a E F 1 \alpha)$ gene (GenBank accession number XM_004307362), previously described as a stable reference gene for $F$. ananassa (Guidarelli et al. 2011). Amplification efficiencies and cycle threshold values were determined for each gene, with the slope of a linear regression model using the LinRegPCR software (Ruijter et al. 2009). These profiles were estimated in relation to $F a E F 1 \alpha$ reference gene using fgStatistics software, based on previously published algorithms (Pfaffl 2001). Two biological replicates with three technical replicates were used for the genes. Each gene expression was expressed as the ratio between AsES and mock expression levels. Thus, values above the dot line in the graphic mean that AsES upregulates the gene, whereas below it, AsES downregulates it.

\section{Primer design.}

All primers used in this study were designed using the software Primer Express (Applied Biosystems). For FaPR1, FaPG1, FaCHI23, FaFLS, FaRBOH-D, FaRBOH-F, and $F a P R X 27$, primers were designed from free access $F$. ananassa nucleotide sequences available in the GenBank database at the

Table 1. Primers used for quantitative polymerase chain reaction in this study ${ }^{\mathrm{a}}$

\begin{tabular}{|c|c|c|c|}
\hline Genes & Name and origin & Primers sequences & Accession no. \\
\hline$F a E F-1 \alpha$ & Celular elongation factor-Tu (Fragaria $\times$ ananassa) & $\begin{array}{l}\text { Fw 5'-CCCCCACTTGGTCGTTTTG } \\
\text { Rv 5'-TGATGACTCCCACAGCAA }\end{array}$ & BK009992 \\
\hline FaPRl & Pathogenesis related protein 1 (Fragaria $\times$ ananassa) & $\begin{array}{l}\text { Fw 5'-CAAAGAGCTCCGGCGACTT } \\
\text { Rv 5'-TCTCCCACCCACAGGTTCAC }\end{array}$ & AB462752 \\
\hline FaPG1 & Poligalacturonase (Fragaria $\times$ ananassa) & $\begin{array}{l}\text { Fw 5'-CGTCAAAGCACCGGGAGATA } \\
\text { Rv 5'-GGTTGAGCGCCCCATATG }\end{array}$ & DQ458990 \\
\hline FaMYB30 & HR-marker gene (Fragaria $\times$ ananassa) & $\begin{array}{l}\text { Fw 5'-TGCCGGCTCAGATGGACTA } \\
\text { Rv 5'-TCGGTGAAGTTACCGCGTTT }\end{array}$ & BK009993 \\
\hline FaRBOH-D & Respiratory burst oxidase homolog D (Fragaria $\times$ ananassa $)$ & $\begin{array}{l}\text { Fw 5'-TTACCTCTGCACCGGGAGAT } \\
\text { Rv 5'-GAGTCCAATCCCCGAGTGTTC }\end{array}$ & KX583680.1 \\
\hline FaRBOH-F & Respiratory burst oxidase homolog $\mathrm{F}$ (Fragaria $\times$ ananassa) & $\begin{array}{l}\text { Fw 5'-CCCAGCTGTTTCCCCATTT } \\
\text { Rv 5'-CTCCGGGAGCAGACGTAAT }\end{array}$ & KX583677.1 \\
\hline $\mathrm{FaCHI} 23$ & Chalcone isomerase 23 (Fragaria $\times$ ananassa) & $\begin{array}{l}\text { Fw 5'-GCTGACGGGCCAGCAAT } \\
\text { Rv 5'-TCCAAATGGCAACACAATTCTC }\end{array}$ & AB201755 \\
\hline FaFLS & Flavonol synthase $($ Fragaria $\times$ ananassa) & $\begin{array}{l}\text { Fw 5'-CCCGCCCTGATCTTGCT } \\
\text { Rv 5'-TGAGGGCGGACATGTCAGTA }\end{array}$ & DQ087252 \\
\hline FaGSL5 & Glucan synthase-like 5 (Fragaria $\times$ ananassa) & $\begin{array}{l}\text { Fw 5'-GGCACTTAAAATGCGGAATCTG } \\
\text { Rv 5'-GATCGTAGGCTTCCGGATACC }\end{array}$ & BK009994 \\
\hline FaPRX27 & Peroxidase27 (Fragaria $\times$ ananassa) & $\begin{array}{l}\text { Fw 5'-CACCAGCTTGCCACAGACAA } \\
\text { Rv 5'-CTGGCTTTTGGCCATCTTCT }\end{array}$ & AFQ36036 \\
\hline FaSAGT & SA glycosiltransferase ${ }^{\mathrm{b}}($ Fragaria $\times$ ananassa $)$ & $\begin{array}{l}\text { Fw 5'-CAGGCCAGTGTGGCAACA } \\
\text { Rv 5'-TGCGGATGGAATTCGACTCT }\end{array}$ & CO817016.1 \\
\hline FaSAMES & SA methylesterase (Fragaria $\times$ ananassa) & $\begin{array}{l}\text { Fw 5'-GGCATCGACACCAAGTCCAT } \\
\text { Rv 5'-TGGAGCAAGTGATCCAATCAAC }\end{array}$ & BK009995 \\
\hline
\end{tabular}


National Center for Biotechnology Information web site. For FaSAGT, primers were designed from an available expressed sequence tag sequence for $F$. ananassa. An indirect primer design strategy was applied for $E F-1 \alpha, M Y B 30, G S L 5$, and SAMES genes, whose sequences were not available for $F$. ananassa. Briefly, the homologs genes candidates were searched with F. vesca, A. thaliana, and Nicotiana benthamiana (for SAMES) with BLAST-N against the sequences from the de novo wholegenome strawberry sequencing project (Hirakawa et al. 2014), in order to identify the $F$. ananassa contig putatively containing the candidate gene. Then, the A. thaliana corresponding protein sequence and the $F$. ananassa DNA contig were used for proteinbased prediction of RNAm and protein sequences with the software FGENESH+ (Solovyev 2007) for each $F$. ananassa gene. To confirm the identity of the predicted protein, a BLAST$\mathrm{P}$ search was carried out. GenBank accession number for each sequence is detailed in Table 1.

\section{Data analysis.}

Error bars in the plots correspond to standard error (SE) for each time point. $\mathrm{SE}$ was calculated as $\mathrm{SE}=\mathrm{SD} / \sqrt{n}$, where $\mathrm{SD}$ is the standard deviation of data values at each time point. Statistical analysis for biphasic ROS, SA, and PC quantification was carried out using InfoStat software, version 2013. When relative values (AsES/mock) were represented (i.e., ROS and PC quantification), a bilateral $t$ test $(P$ value $\leq 0.05)$ was performed in order to determine differences between AsES and mock means and significant differences were indicated by asterisks. For the SA assay, analysis of variance followed by least significant difference test $(P$ value $\leq 0.05)$ was performed and significant differences were indicated by letters. For qPCR data analysis, fgStatistics software interface $(P$ value $<0.05)$ was used as indicated above and significant differences between mean expression values of mockand AsES-treated plants were indicated by asterisks.

\section{ACKNOWLEDGMENTS}

Authors are grateful to the Active Germplasm Bank of Strawberry (National University of Tucumán) and C. Lemme for providing micropropagated strawberry plants. Thanks are also extended to B. Welin for critically reviewing the manuscript. This work was supported by funds to J. C. DíazRicci, from PICT 2013-2075 and CIUNT 26-544, and to A. P. Castagnaro from collaboration agreement between ITANOA and BIAGRO Res. 4508/15. The funding agencies had no role in study, design, collection, analysis and interpretation of data, decision to publish, or writing of the report.

\section{LITERATURE CITED}

Alvarez, M. E., Pennell, R. I., Meijer, P. J., Ishikawa, A., Dixon, R. A., and Lamb, C. 1998. Reactive oxygen intermediates mediate a systemic signal network in the establishment of plant immunity. Cell 92:773-784.

Amil-Ruiz, F., Blanco-Portales, R., Muñoz-Blanco, J., and Caballero, J. L. 2011. The strawberry plant defense mechanism: A molecular review. Plant Cell Physiol. 52:1873-1903.

An, C., and Mou, Z. 2011. Salicylic acid and its function in plant immunity. J. Integr. Plant Biol. 53:412-428.

Benikhlef, L., L'Haridon, F., Abou-Mansour, E., Serrano, M., Binda, M., Costa, A., Lehmann, S., and Métraux, J. P. 2013. Perception of soft mechanical stress in Arabidopsis leaves activates disease resistance. BMC Plant Biol. 13:133.

Bethke, P. C., and Jones, R. L. 2001. Cell death of barley aleurone protoplasts is mediated by reactive oxygen species. Plant J. 25:19-29.

Boller, T., and Felix, G. 2009. A renaissance of elicitors: Perception of microbe-associated molecular patterns and danger signals by patternrecognition receptors. Annu. Rev. Plant Biol. 60:379-406.

Bolwell, G. P., Bindschedler, L. V., Blee, K. A., Butt, V. S., Davies, D. R., Gardner, S. L., Gerrish, C., and Minibayeva, F. 2002. The apoplastic oxidative burst in response to biotic stress in plants: A three-component system. J. Exp. Bot. 53:1367-1376.

Canonne, J., Marino, D., Jauneau, A., Pouzet, C., Brière, C., Roby, D., and Rivas, S. 2011. The Xanthomonas type III effector XopD targets the
Arabidopsis transcription factor MYB30 to suppress plant defense. Plant Cell 23:3498-3511

Castagnaro, A. P., Díaz-Ricci, J. C., Chalfoun, N. R., Racedo, J., and Salazar, S. M. September 2012. Polypeptide that induces defense against biotic stress in plants, nucleotide sequence that codes for same microorganism, compositions and methods. International patent WO2012123614 (A1). Approved in AR, EP, US, RU, PE, NZ, MX, CO, $\mathrm{CA}$, and AU. Published online. https://worldwide.espacenet.com/ publicationDetails/originalDocument $? \mathrm{FT}=\mathrm{D} \&$ date $=20120920 \& \mathrm{DB}=\&$ locale $=$ en_EP $\& C C=W O \& N R=2012123614 A 1 \& K C=A 1 \& N D=5$

Chalfoun, N. R. 2009. Caracterización molecular de la respuesta defensiva de la frutilla mediada por moléculas inductoras de un patógeno avirulento Ph.D. thesis. Universidad Nacional de Tucumán, San Miguel de Tucumán, Argentina.

Chalfoun, N. R., Grellet-Bournonville, C. F., Martínez-Zamora, M. G., DíazPerales, A., Castagnaro, A. P., and Díaz-Ricci, J. C. 2013. Purification and characterization of AsES protein: A subtilisin secreted by Acremonium strictum is a novel plant defense elicitor. J. Biol. Chem. 288:14098-14113.

Chaturvedi, R., and Shah, J. 2007. Salicylic acid in plant disease resistance. Pages 335-370 in: Salicylic Acid-A Plant Hormone. S. Hayat and A. Ahmad, eds. Springer, Dordrecht, The Netherlands.

Chisholm, S. T., Coaker, G., Day, B., and Staskawicz, B. J. 2006. Hostmicrobe interactions: Shaping the evolution of the plant immune response. Cell 124:803-814.

Choquer, M., Fournier, E., Kunz, C., Levis, C., Pradier, J. M., Simon, A., and Viaud, M. 2007. Botrytis cinerea virulence factors: New insights into a necrotrophic and polyphageous pathogen. FEMS Microbiol. Lett. 277: $1-10$

Daniel, X., Lacomme, C., Morel, J. B., and Roby, D. 1999. A novel myb oncogene homologue in Arabidopsis thaliana related to hypersensitive cell death. Plant J. 20:57-66.

Dat, J. F., Pellinen, R., Beeckman, T., Van De Cotte, B., Langebartels, C., Kangasjärvi, J., Inzé, D., and Van Breusegem, F. 2003. Changes in hydrogen peroxide homeostasis trigger an active cell death process in tobacco. Plant J. 33:621-632.

De Wit, P. J. G. M., Mehrabi, R., Van den Burg, H. A., and Stergiopoulos, I. 2009. Fungal effector proteins: Past, present and future. Mol. Plant Pathol. 10:735-747.

Delaney, T. P., Uknes, S., Vernooij, B., Friedrich, L., Weymann, K., Negrotto, D., Gaffney, T., Gut-Rella, M., Kessmann, H., Ward, E., and Ryals, J. 1994. A central role of salicylic acid in plant disease resistance. Science 266:1247-1250.

Deslandes, L., and Rivas, S. 2012. Catch me if you can: Bacterial effectors and plant targets. Trends Plant Sci. 17:644-655.

Dixon, R. J., and Lamb, C. J. 1990. Molecular communication in interactions between plants and microbial pathogens. Annu. Rev. Plant Physiol. Plant Mol. Biol. 41:339-367.

Dizeo de Strittmater, C. 1973. Nueva técnica de diafanización. Bol. Soc. Argent. Bot. 15:126-129.

Doke, N. 1983. Generation of superoxide anion by potato tuber protoplasts during the hypersensitive response to hyphal wall components of Phytopthora infestans and specific inhibition of the reaction by suppressors of hypersensitivity. Physiol. Plant Pathol. 23:359-367.

Durrant, W. E., and Dong, X. 2004. Systemic acquired resistance. Annu. Rev. Phytopathol. 42:185-209.

Ferrari, S., Savatin, D. V., Sicilia, F., Gramegna, G., Cervone, F., and Lorenzo, G. D. 2013. Oligogalacturonides: Plant damage-associated molecular patterns and regulators of growth and development. Front. Plant Sci. 4:49.

Flor, H. H. 1971. The current status of the gene-for gene concept. Annu Rev. Phytopathol. 9:275-296.

Freytag, S., Arabatzis, N., Hahlbrock, K., and Schmelzer, E. 1994. Reversible cytoplasmic rearrangements precede wall apposition, hypersensitive cell-death and defense-related gene activation in potato/Phytophthora infestans interactions. Planta 194:123-135.

Froidure, S., Roby, D., and Rivas, S. 2010. Expression of the Arabidopsis transcription factor AtMYB30 is post-transcriptionally regulated. Plan Physiol. Biochem. 48:735-739.

Fu, Z. Q., and Dong, X. 2013. Systemic acquired resistance: Turning local infection into global defense. Annu. Rev. Plant Biol. 64:839-863.

Gaffney, T., Friedrich, L., Vernooij, B., Negrotto, D., Nye, G., Uknes, S., Ward, E., Kessmann, H., and Ryals, J. 1993. Requirement of salicylic acid for the induction of systemic acquired resistance. Science 261: 754-756.

Galletti, R., Denoux, C., Gambetta, S., Dewdney, J., Ausubel, F. M., De Lorenzo, G., and Ferrari, S. 2008. The AtrbohD-mediated oxidative burst elicited by oligogalacturonides in Arabidopsis is dispensable for 
the activation of defense responses effective against Botrytis cinerea. Plant Physiol. 148:1695-1706.

Garcia-Brugger, A., Lamotte, O., Vandelle, E., Bourque, S., Lecourieux, D. Poinssot, B., Wendehenne, D., and Pugin, A. 2006. Early signaling events induced by elicitors of plant defenses. Mol. Plant-Microbe Interact. 19:711-724.

Garcion, C., Lamotte, O., and Métraux, J. P. 2007. Mechanisms of defence to pathogens: Biochemistry and physiology. Pages 109-132 in: Induced Resistance for Plant Defence: A Sustainable Approach to Crop Protection. D. Walters, A. Newton, and G. D. Lyon, eds. Blackwell Press, Oxford.

Glazebrook, J. 2005. Contrasting mechanisms of defense against biotrophic and necrotrophic pathogens. Annu. Rev. Phytopathol. 43:205-227.

Govrin, E. M., and Levine, A. 2002. Infection of Arabidopsis with a necrotrophic pathogen, Botrytis cinerea, elicits various defense responses but does not induce systemic acquired resistance (SAR). Plant Mol. Biol. 48:267-276

Graham, M. Y., Weidner, J., Wheeler, K., Pelow, M. J., and Graham, T. L. 2003. Induced expression of pathogenesis-related protein genes in soybean by wounding and the Phytophthora sojae cell wall glucan elicitor. Physiol. Mol. Plant Pathol. 63:141-149.

Graham, T. L., and Graham, M. Y. 1991. Cellular coordination of molecular responses in plant defense. Mol. Plant-Microbe Interact. 4:415-422.

Grant, J. J., Yun, B. W., and Loake, G. J. 2000. Oxidative burst and cognate redox signalling reported by luciferase imaging: Identification of a signal network that functions independently of ethylene, SA and Me-JA but is dependent on MAPKK activity. Plant J. 24:569-582.

Grayer, R. J., and Kokubun, T. 2001. Plant-fungal interactions: The search for phytoalexins and other antifungal compounds from higher plants. Phytochemistry 56:253-263.

Greenberg, J. T., Guo, A., Klessig, D. F., and Ausubel, F. M. 1994. Programmed cell death in plants: A pathogen-triggered response activated coordinately with multiple defense functions. Cell 77:551-563.

Greenberg, J. T., and Yao, N. 2004. The role and regulation of programmed cell death in plant-pathogen interactions. Cell. Microbiol. 6:201-211.

Grellet-Bournonville, C. F., Martinez-Zamora, M. G., Castagnaro, A. P. and Díaz-Ricci, J. C. 2012. Temporal accumulation of salicylic acid activates the defense response against Colletotrichum in strawberry. Plant Physiol. Biochem. 54:10-16.

Guidarelli, M., Carbone, F., Mourgues, F., Perrotta, G., Rosati, C., Bertolinia, P., and Baraldia, E. 2011. Colletotrichum acutatum interactions with unripe and ripe strawberry fruits and differential responses at histological and transcriptional levels. Plant Pathol. 60:685-697.

Hael-Conrad, V., Abou-Mansour, E., Díaz-Ricci, J. C., Métraux, J. P., and Serrano, M. 2015. The novel elicitor AsES triggers a defense response against Botrytis cinerea in Arabidopsis thaliana. Plant Sci. 241:120-127.

Hammond-Kosack, K. E., and Jones, J. D. G. 1996. Resistance genedependent plant defense responses. Plant Cell 8:1773-1791.

Harborne, J. B. 1999. The comparative biochemistry of phytoalexin induction in plants. Biochem. Syst. Ecol. 27:335-367.

Heath, M. C. 1998. Involvement of reactive oxygen species in the response of resistant (hypersensitive) or susceptible cowpeas to the cowpea rust fungus. New Phytol. 138:251-263.

Heath, M. C. 2000. Hypersensitive response-related death. Pages 77-90 in: Programmed Cell Death in Higher Plants. E. Lam, H. Fukuda, and J. Greenberg, eds. Springer, Dordrecht, The Netherlands.

Henry, G., Thonart, P., and Ongena, M. 2012. PAMPs, MAMPs, DAMPs and others: An update on the diversity of plant immunity elicitors. Biotechnol. Agron. Soc. Environ. 16:257-268.

Hirakawa, H., Shirasawa, K., Kosugi, S., Tashiro, K., Nakayama, S., Yamada, M., Kohara, M., Watanabe, A., Kishida, Y., Fujishiro, T., Tsuruoka, H., Minami, C., Sasamoto, S., Kato, M., Nanri, K., Komaki, A., Yanagi, T., Guoxin, Q., Maeda, F., Ishikawa, M., Kuhara, S., Sato, S., Tabata, S., and Isobe, S. N. 2014. Dissection of the octoploid strawberry genome by deep sequencing of the genomes of Fragaria species. DNA Res. 21:169-181.

Hirst, R. A., Harrison, C., Hirota, K., and Lambert, D. G. 1999. Measurement of $\left[\mathrm{Ca}^{2+}\right] \mathrm{i}$ in whole cell suspensions using fura-2. Methods Mol. Biol. 114:31-39.

Hoeberichts, F. A., and Woltering, E. J. 2003. Multiple mediators of plant programmed cell death: Interplay of conserved cell death mechanisms and plant-specific regulators. BioEssays 25:47-57.

Hukkanen, A. T., Kokko, H. I., Buchala, A. J., McDougall, G. J., Stewart, D., Kärenlampi, S. O., and Karjalainen, R. O. 2007. Benzothiadiazole induces the accumulation of phenolics and improves resistance to powdery mildew in strawberries. J. Agric. Food Chem. 55:1862-1870.

Humphreys, J. M., and Chapple, C. 2002. Rewriting the lignin roadmap. Curr. Opin. Plant Biol. 5:224-229.
Jacobs, A. K., Lipka, V., Burton, R. A., Panstruga, R., Strizhov, N., SchulzeLefert, P., and Fincher, G. B. 2003. An Arabidopsis callose synthase, GSL5, is required for wound and papillary callose formation. Plant Cell 15:2503-2513.

Jones, J. D. G., and Dangl, J. L. 2006. The plant immune system. Nature 444:323-329.

Kasparovsky, T., Blein, J. P., and Mikes, V. 2004. Ergosterol elicits oxidative burst in tobacco cells via phospholipase A2 and protein kinase C signal pathway. Plant Physiol. Biochem. 42:429-435.

Klessig, D. F., Durner, J., Noad, R., Navarre, D. A., Wendehenne, D. Kumar, D., Zhou, J. M., Shah, J., Zhang, S., Kachroo, P., Trifa, Y., Pontier, D., Lam, E., and Silva, H. 2000. Nitric oxide and salicylic acid signaling in plant defense. Proc. Natl. Acad. Sci. U.S.A. 97:8849-8855

Koga, H., Zeyen, R. J., Bushnell, W. R., and Ahlstrand, G. G. 1988 Hypersensitive cell death, autofluorescence, and insoluble silicon accumulation in barley leaf epidermal cells under attack by Erysiphe graminis $\mathrm{f}$. sp. hordei. Physiol. Mol. Plant Pathol. 32:395-409.

Koornneef, A., and Pieterse, C. M. J. 2008. Cross talk in defense signaling. Plant Physiol. 146:839-844.

Kuta, D. D., and Gaivaronskaya, L. M. 2004. $\mathrm{Ca}^{2+}$ and reactive oxygen species are involved in the defense responses of rice callus culture to rice blast disease. Acad. J. 3:76-81.

Lam, E. 2004. Controlled cell death, plant survival and development. Nat. Rev. Mol. Cell Biol. 5:305-315.

Lam, E., Kato, N., and Lawton, M. 2001. Programmed cell death, mitochondria and the plant hypersensitive response. Nature 411: 848-853.

Lamb, C., and Dixon, R. A. 1997. The oxidative burst in plant disease resistance. Annu. Rev. Plant Physiol. Plant Mol. Biol. 48:251-275.

Lamotte, O., Courtois, C., Barnavon, L., Pugin, A., and Wendehenne, D. 2005. Nitric oxide in plants: The biosynthesis and cell signalling properties of a fascinating molecule. Planta 221:1-4.

Lecourieux, D., Mazars, C., Pauly, N., Ranjeva, R., and Pugin, A. 2002. Analysis and effects of cytosolic free calcium increases in response to elicitors in Nicotiana plumbaginifolia cells. Plant Cell 14:2627-2641.

Lewis, N. G. 1999. A 20(th) century roller coaster ride: A short account of lignification. Curr. Opin. Plant Biol. 2:153-162.

Li, J., Zhang, Z. G., Ji, R., Wang, Y. C., and Zheng, X. B. 2006. Hydrogen peroxide regulates elicitor PB90-induced cell death and defense in nonheading Chinese cabbage. Physiol. Mol. Plant Pathol. 67:220-230.

Lucena, M. A., Romero-Aranda, R., Mercado, J. A., Cuartero, J., Valpuesta, V., and Quesada, M. A. 2003. Structural and physiological changes in the roots of tomato plants over-expressing a basic peroxidase. Physiol. Plant. 118: 422-429.

Lüthje, S., Meisrimler, C. N., Hopff, D., and Möller, B. 2011. Phylogeny, topology, structure and functions of membrane-bound class III peroxidases in vascular plants. Phytochemistry 72:1124-1135.

Malamy, J., Carr, J. P., Klessig, D. F., and Raskin, I. 1990. Salicylic acid: A likely endogenous signal in the resistance response of tobacco to viral infection. Science 250:1002-1004.

Mathé, C., Barre, A., Jourda, C., and Dunand, C. 2010. Evolution and expression of class III peroxidases. Arch. Biochem. Biophys. 500:58-65.

Mauch-Mani, B., and Métraux, J. P. 1998. Salicylic acid and systemic acquired resistance to pathogen attack. Ann. Bot. (Lond.) 82:535-540.

McLusky, S. R., Bennett, M. H., Beale, M. H., Lewis, M. J., Gaskin, P., and Mansfield, J. W. 1999. Cell wall alterations and localized accumulation of feruloyl-3-methoxytyramine in onion epidermis at sites of attempted penetration by Botrytis allii are associated with actin polarisation, peroxidase activity and suppression of flavonoid biosynthesis. Plant J. 17:523-534.

Métraux, J. P., Signer, H., Ryals, J., Ward, E., Wyss-Benz, M., Gaudin, J. Raschdorf, K., Schmid, E., Blum, W., and Inverardi, B. 1990. Increase in salicylic acid at the onset of systemic acquired resistance in cucumber. Science 250:1004-1006.

Moallaei, H., Zaini, F., Larcher, G., Beucher, B., and Bouchara, J. P. 2006. Partial purification and characterization of a $37 \mathrm{kDa}$ extracellular proteinase from Trichophyton vanbreuseghemii. Mycopathologia 161: 369-375.

Morales, J., Kadota, Y., Zipfel, C., Molina, A., and Torres, M. A. 2016. The Arabidopsis NADPH oxidases $R b o h D$ and $R b o h F$ display differential expression patterns and contributions during plant immunity. J. Exp. Bot. 67:1663-1676

Mur, L. A., Kenton, P., Lloyd, A. J., Ougham, H., and Prats, E. 2008. The hypersensitive response; the centenary is upon us but how much do we know? J. Exp. Bot. 59:501-520.

Murashige, T., and Skoog, F. 1962. A revised medium for rapid growth and bio assays with tobacco tissue cultures. Physiol. Plant. 15:473-497. 
Newman, M. A., Sundelin, T., Nielsen, J. T., and Erbs, G. 2013. MAMP (microbe-associated molecular pattern) triggered immunity in plants. Front. Plant Sci. 4:139.

Nicholson, R. L., and Hammerschmidt, R. 1992. Phenolic compounds and their role in disease resistance. Annu. Rev. Phytopathol. 30:369-389.

Osorio, S., Bombarely, A., Giavalisco, P., Usadel, B., Stephens, C. Aragüez, I., Medina-Escobar, N., Botella, M. A., Fernie, A. R., and Valpuesta, V. 2011. Demethylation of oligogalacturonides by FaPE1 in the fruits of the wild strawberry Fragaria vesca triggers metabolic and transcriptional changes associated with defence and development of the fruit. J. Exp. Bot. 62:2855-2873.

Pauw, B., van Duijn, B., Kijne, J. W., and Memelink, J. 2004. Activation of the oxidative burst by yeast elicitor in Catharanthus roseus cells occurs independently of the activation of genes involved in alkaloid biosynthesis. Plant Mol. Biol. 55:797-805.

Pedley, K. F., and Martin, G. B. 2005. Role of mitogen-activated protein kinases in plant immunity. Curr. Opin. Plant Biol. 8:541-547.

Pfaffl, M. W. 2001. A new mathematical model for relative quantification in real-time RT-PCR. Nucleic Acids Res. 29:e45.

Racedo, J., Salazar, S. M., Castagnaro, A. P., and Díaz-Ricci, J. C. 2013. A strawberry disease caused by Acremonium strictum. Eur. J. Plant Pathol. 137:649-654.

Ring, L., Yeh, S. Y., Hücherig, S., Hoffmann, T., Blanco-Portales, R., Fouche, M., Villatoro, C., Denoyes, B., Monfort, A., Caballero, J. L., Muñoz-Blanco, J., Gershenson, J., and Schwab, W. 2013. Metabolic interaction between anthocyanin and lignin biosynthesis is associated with peroxidase FaPRX27 in strawberry fruit. Plant Physiol. 163:43-60.

Robert-Seilaniantz, A., Grant, M., and Jones, J. D. G. 2011. Hormone crosstalk in plant disease and defense: More than just jasmonatesalicylate antagonism. Annu. Rev. Phytopathol. 49:317-343.

Robert-Seilaniantz, A., Navarro, L., Bari, R., and Jones, J. D. 2007. Pathological hormone imbalances. Curr. Opin. Plant Biol. 10:372-379.

Ruijter, J. M., Ramakers, C., Hoogaars, W. M., Karlen, Y., Bakker, O., van den Hoff, M. J., and Moorman, A. F. 2009. Amplification efficiency: Linking baseline and bias in the analysis of quantitative PCR data. Nucleic Acids Res. 37:e45.

Ryals, J. A., Neuenschwander, U. H., Willits, M. G., Molina, A., Steiner, H. Y., and Hunt, M. D. 1996. Systemic acquired resistance. Plant Cell 8: 1809-1819.

Sagi, M., and Fluhr, R. 2001. Superoxide production by plant homologues of the gp9 $91^{\text {phox }}$ NADPH oxidase. Modulation of activity by calcium and by tobacco mosaic virus infection. Plant Physiol. 126:1281-1290.

Salazar, S., Castagnaro, A., Arias, M., Chalfoun, N., Tonello, U., and DíazRicci, J. C. 2007. Induction of a defense response in strawberry mediated by an avirulent strain of Colletotrichum. Eur. J. Plant Pathol. 117: 109-122.

Sasabe, M., Takeuchi, K., Kamoun, S., Ichinose, Y., Govers, F., Toyoda, K., Shiraishi, T., and Yamada, T. 2000. Independent pathways leading to apoptotic cell death, oxidative burst and defense gene expression in response to elicitin in tobacco cell suspension culture. Eur. J. Biochem. 267:5005-5013.

Singleton, V. L., Orthofer, R., and Lamuela-Raventos, R. M. 1999. Analysis of total phenols and other oxidation substrates and antioxidants by means of Folin-Ciocalteu reagent. Methods Enzymol. 299:152-178.

Skalamera, D., and Heath, M. C. 1998. Changes in the cytoskeleton accompanying infection-induced nuclear movements and the hypersensitive response in plant cells invaded by rust fungi. Plant J. 16: 191-200.

Solovyev, V. V. 2007. Statistical approaches in Eukaryotic gene prediction. Page 1616 in: Handbook of Statistical Genetics. D. Balding, C. Cannings, and M. Bishop, eds. Wiley-Interscience, West Sussex, U.K.

Thordal-Christensen, H., Zhang, Z., Wei, Y., and Collinge, D. B. 1997. Subcellular localization of $\mathrm{H}_{2} \mathrm{O}_{2}$ in plants. $\mathrm{H}_{2} \mathrm{O}_{2}$ accumulation in papillae and hypersensitive response during the barley-powdery mildew interaction. Plant J. 11:1187-1194.
Torres, M. A., and Dangl, J. L. 2005. Functions of the respiratory burst oxidase in biotic interactions, abiotic stress and development. Curr. Opin. Plant Biol. 8:397-403.

Torres, M. A., Dangl, J. L., and Jones, J. D. G. 2002. Arabidopsis gp91 ${ }^{\text {phox }}$ homologues AtrbohD and AtrbohF are required for accumulation of reactive oxygen intermediates in the plant defense response. Proc. Natl. Acad. Sci. U.S.A. 99:517-522.

Torres, M. A., Jones, J. D. G., and Dangl, J. L. 2006. Reactive oxygen species signaling in response to pathogens. Plant Physiol. 141:373-378.

Tortora, M. L., Díaz-Ricci, J. C., and Pedraza, R. O. 2012. Protection of strawberry plants (Fragaria ananassa Duch.) against anthracnose disease induced by Azospirillum brasilense. Plant Soil 356:279-290.

Underwood, W. 2012. The plant cell wall: A dynamic barrier against pathogen invasion. Front. Plant Sci. 3:85.

Vailleau, F., Daniel, X., Tronchet, M., Montillet, J. L., Triantaphylidès, C., and Roby, D. 2002. A R2R3-MYB gene, AtMYB30, acts as a positive regulator of the hypersensitive cell death program in plants in response to pathogen attack. Proc. Natl. Acad. Sci. U.S.A. 99:10179-10184.

Valério, L., De Meyer, M., Penel, C., and Dunand, C. 2004. Expression analysis of the Arabidopsis peroxidase multigenic family. Phytochemistry $65: 1331-1342$.

van Doorn, W. G., Beers, E. P., Dangl, J. L., Franklin-Tong, V. E., Gallois, P., Hara-Nishimura, I., Jones, A. M., Kawai-Yamada, M., Lam, E., Mundy, J., Mur, L. A., Petersen, M., Smertenko, A., Taliansky, M., Van Breusegem, F., Wolpert, T., Woltering, E., Zhivotovsky, B., and Bozhkov, P. V. 2011. Morphological classification of plant cell deaths. Cell Death Differ. 18:1241-1246.

van Kan, J. A. 2006. Licensed to kill: The lifestyle of a necrotrophic plant pathogen. Trends Plant Sci. 11:247-253.

Van Loon, L. C. 1997. Induced resistance in plants and the role of pathogenesis-related proteins. Eur. J. Plant Pathol. 103:753-765.

Van Loon, L. C., and van Strien, E. A. 1999. The families of pathogenesisrelated proteins, their activities, and comparative analysis of PR-1 type proteins. Physiol. Mol. Plant Pathol. 55:85-97.

Walters, D. R., Ratsep, J., and Havis, N. D. 2013. Controlling crop diseases using induced resistance: Challenges for the future. J. Exp. Bot. 64: 1263-1280.

Wang, H., Yang, X., Guo, L., Zeng, H., and Qiu, D. 2015. PeBL1, a novel protein elicitor from Brevibacillus laterosporus strain A60, activates defense responses and systemic resistance in Nicotiana benthamiana. Appl. Environ. Microbiol. 81:2706-2716.

Wiesel, L., Newton, A. C., Elliott, I., Booty, D., Gilroy, E. M., Birch, P. R. J., and Hein, I. 2014. Molecular effects of resistance elicitors from biological origin and their potential for crop protection. Front. Plant Sci. 5:1-13.

Williamson, B., Tudzynski, B., Tudzynski, P., and van Kan, J. A. 2007. Botrytis cinerea: The cause of grey mould disease. Mol. Plant Pathol. 8: 561-580.

Yun, M. H., Torres, P. S., El Oirdi, M., Rigano, L. A., González-Lamothe, R., Marano, M. R., Castagnaro, A. P., Dankert, M. A., Bouarab, K., and Vojnov, A. A. 2006. Xanthan induces plant susceptibility by suppressing callose deposition. Plant Physiol. 141:178-187.

Zhong, R., and Ye, Z. H. 2009. Transcriptional regulation of lignin biosynthesis. Plant Signal. Behav. 4:1028-1034.

Zipfel, C., Robatzek, S., Navarro, L., Oakeley, E. J., Jones, J. D. G., Felix, G., and Boller, T. 2004. Bacterial disease resistance in Arabidopsis through flagellin perception. Nature 428:764-767.

\section{AUTHOR-RECOMMENDED INTERNET RESOURCES}

fgStatistics software: https://sites.google.com/site/fgStatistics InfoStat versión 2013 software: http://www.infostat.com.ar

National Center for Biotechnology Information (NCBI) BLAST-N search tool: http://blast.ncbi.nlm.nih.gov/Blast.cgi

NCBI GenBank database: https://www.ncbi.nlm.nih.gov/genbank 